IZA DP No. 10231

Trade Shocks and the Provision of Local Public Goods

Leo Feler

Mine Z. Senses

September 2016 


\title{
Trade Shocks and the Provision of Local Public Goods
}

\author{
Leo Feler \\ Johns Hopkins University \\ Mine Z. Senses \\ Johns Hopkins University \\ and IZA \\ Discussion Paper No. 10231 \\ September 2016 \\ IZA \\ P.O. Box 7240 \\ 53072 Bonn \\ Germany \\ Phone: +49-228-3894-0 \\ Fax: +49-228-3894-180 \\ E-mail: iza@iza.org
}

\begin{abstract}
Any opinions expressed here are those of the author(s) and not those of IZA. Research published in this series may include views on policy, but the institute itself takes no institutional policy positions. The IZA research network is committed to the IZA Guiding Principles of Research Integrity.

The Institute for the Study of Labor (IZA) in Bonn is a local and virtual international research center and a place of communication between science, politics and business. IZA is an independent nonprofit organization supported by Deutsche Post Foundation. The center is associated with the University of Bonn and offers a stimulating research environment through its international network, workshops and conferences, data service, project support, research visits and doctoral program. IZA engages in (i) original and internationally competitive research in all fields of labor economics, (ii) development of policy concepts, and (iii) dissemination of research results and concepts to the interested public.
\end{abstract}

IZA Discussion Papers often represent preliminary work and are circulated to encourage discussion. Citation of such a paper should account for its provisional character. A revised version may be available directly from the author. 
IZA Discussion Paper No. 10231

September 2016

\section{ABSTRACT}

\section{Trade Shocks and the Provision of Local Public Goods*}

We analyze the impact of trade-induced income shocks on the size of local government, and the provision of public services. Areas in the US with declining labor demand and incomes due to increasing import competition from China experience relative declines in housing prices and business activity. Since local governments are disproportionately funded through property and sales taxation, declining property values and a decrease in economic activity translate into less revenue, which constrains the ability of local governments to provide public services. State and federal governments have limited ability to smooth local shocks, and the impact on the provision of public services is compounded when local income shocks are highly correlated with shocks in the rest of the state. The outcome is greater inequality not only in incomes but also in the quality of public services and amenities across US jurisdictions.

JEL Classification: F14, F16, H41, H70, R12, R23

Keywords: trade shocks, housing prices, intergovernmental transfers, public finance, public goods

Corresponding author:

Mine Z. Senses

School of Advanced International Studies (SAIS)

Johns Hopkins University

1717 Massachusetts Avenue, N.W.

Washington D.C., 20036

USA

E-mail: msenses@jhu.edu

\footnotetext{
* We are grateful to Leah Boustan, Leah Brooks, David Dorn, Ilenin Kondo, Pravin Krishna and Christina Tello Trillo for helpful comments and suggestions. Scott Abrahams, James Bisbee, and Christine Jonason provided excellent research assistance.
} 


\section{Introduction}

The size and role of government in an increasingly globalized world is an important but understudied question. While free trade results in gains in aggregate welfare, the distribution of these gains is uneven across regions and segments of the population within a country $1-1$ An increase in trade openness or changes in global patterns of comparative advantage increases the uncertainty associated with these gains, and exposes workers to riskier economic environments ${ }_{2}^{2}$ Governments may play an important role in this context both by mitigating risk through welfare spending (Rodrik, 1998) and by investing in public services such as high quality education and infrastructure to ensure the competitiveness of workers and firms (Sachs, 2011). At the same time, globalization may restrain a governments ability to adjust spending due to budgetary pressures and increased factor mobility (Cerny (1995) and Rodrik (1997)). In this paper we contribute towards an understanding of the impact of globalization on the size of government by studying the effects of local income shocks due to increased imports from China on local government finances and the provision of local public services in the US.

Unlike in other industrialized countries, funding for public services such as education, fire and police protection, parks and recreation, public transport, and public housing for low-income families is highly localized in the US, with heavy reliance on property and sales tax revenues. Local funding of public services allows jurisdictions to tailor spending and service provision according to local priorities. It also leads to vast differences in taxation and the quality of public services. When income shocks differentially affect US localities, these localities correspondingly adjust services according to budget constraints. A decline in the level of local economic activity and incomes in a labor market depresses revenues and restricts the ability of local governments to fund services. Unless federal or state governments provide complete insurance against the decline in revenues, the outcome is a reduction of local government expenditures, leading to worsening measures of public

\footnotetext{
${ }^{1} \mathrm{~A}$ large empirical literature has examined the important question of how trade might affect the wages of workers in different human capital or occupational categories. Feenstra and Hanson (2002), Davidson and Matusz (2004), Goldberg and Pavcnik (2007) and Harrison (2007) provide excellent survey treatments.

${ }^{2}$ International competition, by posing a limit on price variability, could reduce the stabilizing role of prices and expose an economy to higher output volatility (Newbery and Stiglitz, 1984). Similarly, increased openness may increase risk for individual workers due to an increase in the elasticity of labor demand (Rodrik, 1997, Slaughter, 2001, Senses, 2010) and a weakening of domestic institutions for risk-sharing (McLaren and Newman, 2002). Krebs et al. (2010) for Mexico and Krishna and Senses (2014) for the US find a statistically and economically significant association between openness and persistent income risk.
} 
goods provision relative to other parts of the country. As we show in this paper, the incidence of these expenditure cuts typically falls upon those who rely the most on government services, namely low-income households and families with dependent children.

In identifying the effects of changes in local incomes on public good provision, we exploit the variation in trade exposure across US labor markets. Due to differences in initial industry composition, the magnitudes of trade shocks vary across labor markets and lead to differential changes in employment and income (Topalova, 2007; Hakobyan and McLaren, 2010; Autor et al., 2013 Kovak, 2013). The trade shock we consider is the rise in imports from China to the US between 1990 and 2007, as in Autor et al. (2013) 3 $^{3}$ The resulting variation in exposure to Chinese import competition across localities can be viewed as an external shock to individual US labor markets 4

The literature currently documents relative declines in both wages and employment in labor markets that are more exposed to low-income-country import competition. It also finds that negative labor market outcomes spill over to the non-manufacturing sector and continue to persist even when social assistance and trade adjustment programs at the federal level are taken into account (Hakobyan and McLaren, 2010; Autor et al., 2013). In this paper, we extend the analysis of trade shocks by examining whether negative labor market outcomes result in a deterioration of local public finances and services. By focusing on the local public finance implications of trade shocks, our paper complements the findings of the recent literature examining the impact of trade on labor

\footnotetext{
${ }^{3}$ The surge in low-income country imports into the US during this period is mostly driven by China. China's increase in exports can be attributed to internal reforms: the country's transition to a market economy, the migration of over 150 million workers from rural to urban areas, the adoption of foreign technologies, and the country's accession to the WTO.

${ }^{4}$ The increase in Chinese import competition can be considered an external shock to the extent it was not driven by a decline in local productivity or changes in local demand in the US. Following Autor et al. (2013), we use growth in Chinese exports to other high-income countries as an instrument for the growth in US imports from China. The instrumentation strategy we implement resembles the Bartik (1991) instrument commonly used in the public finance and urban economics literatures (e.g. see Baum-Snow and Ferreira (2014) for a review). The Bartik instrument is based on an interaction of cross-sectional differences in base-year industrial composition and national changes in industry employment. The assumption for credible identification is that initial industry composition does not directly predict the outcomes of interest conditional on controls. This is a strong assumption especially when using one-digit sector classifications as is often done to avoid situations where employment in an industry is highly concentrated in a few localities. For our instrument, we use local employment decomposed at the four-digit SIC level and interact these initial shares of local employment with the change in Chinese exports in specific four-digit product categories. Our instrumentation strategy is based not only on initial employment shares and national changes to employment (as is the case with the Bartik instrument), but on initial employment shares in specific industries that directly compete with Chinese imports. Over $75 \%$ of the variation in our instrument is driven by initial differences in employment within manufacturing across localities.
} 
outcomes such as employment, wages, and income. This is important as the response of the local governments, and their ability to provide local services and local amenities, will help mitigate or further amplify the effects of the initial negative economic shock on the locality. The localities that experience a decline in incomes may have greater difficulty in recovering from these shocks if they fail to provide high quality public services ${ }^{5}$

The key findings of this paper are as follows. First, increased competition from Chinese imports negatively affects local finances and the provision of public services across US localities. Specifically, localities that experience a relative decline in employment and incomes due to their differential exposure to Chinese imports experience a relative decline in housing prices and business activity. The resulting decline in local government revenues, mainly due to declining property and sales tax receipts, translates into a decline in local expenditures on almost all major budget items. A $\$ 1000$ increase in Chinese imports per worker results in a relative decline in per capita expenditures on public welfare (by 7.7\%), on public transport (by 2.4\%), on public housing (by $6.8 \%$ ), and on public education (by $0.9 \%$ ); public safety spending remains unchanged.

Second, the demand for local public goods such as education, public safety, and public welfare is increasing more in trade-affected localities when resources for these services are declining or remaining constant. We show that public safety expenditures remain constant at a time when local poverty and unemployment rates are rising, resulting in higher property crime rates (by 3.5\%). Similarly, a relative decline in education spending coincides with an increase in the demand for education as students respond to a deterioration in employment prospects for low-skilled workers by remaining in school longer. The result is an increase in student-teacher ratios in public schools. In localities that are more exposed to trade shocks, we also document an increase in the share of poor and low-income households, which tend to rely more on government services such as public housing and public transportation, both of which experience spending cuts.

Third, state and federal intergovernmental transfers incompletely insure against trade-induced income shocks, especially when local shocks are correlated with shocks in the rest of the state. This

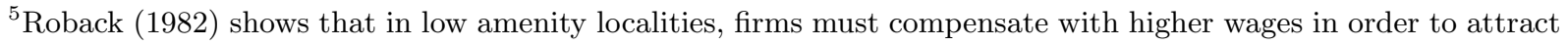
workers. Cullen and Levitt (1999) show that high-income and highly educated families value public safety and are more likely to move in response to an increase in crime rates. Also related is a recent literature that focuses on the impact of trade on social outcomes such as health, education, and crime (McManus and Schaur, 2015, Greenland and Lopresti, 2015 Iyer and Topalova, 2014 Dix-Carneiro et al., 2015). In this paper we highlight the public finance channel as a contributing factor to changes in these social outcomes across US localities.
} 
is important since intergovernmental transfers could theoretically be used to help equalize local per capita expenditures and public good provision across localities. Because intergovernmental transfers do not buffer against local income shocks, there is greater inequality not only in incomes but also in the quality of public services and amenities across US jurisdictions.

The remainder of the paper proceeds as follows. Section 2 provides information on the rise of Chinese imports and discusses the interrelation between local income shocks, public finances, and public service provision in the US. Section 3 presents the empirical framework. Our main results are presented in Section 4, and Section 5 provides extensions and robustness checks to assess the validity of our results. Finally, Section 6 concludes.

\section{Motivation}

Since the early 1990s, the value of China's exports to the rest of the world has grown exponentially due mostly to structural reforms within the Chinese economy. For the US, this growth has translated into greater competition from Chinese imports, which increased more than ten-fold from $\$ 26$ billion in 1991 to $\$ 330$ billion in 2007. For comparison, imports from other countries into the US grew approximately three-fold from $\$ 369$ billion in 1991 to $\$ 992$ billion in 2007. Importantly, there is substantial heterogeneity in exposure to imports from China across industries and localities. Localities in the US that specialize in producing manufactured goods, especially those heavily exported by China, are the most negatively affected by the surge in Chinese competition, whereas localities with majority of employment in industries that do not directly compete with Chinese products are hardly affected at all ${ }^{6}$ Autor et al. (2013) find this heterogeneity in import exposure to be important in explaining the variation in labor market outcomes across the US, with labor markets that are more exposed to import competition from China experiencing relative declines in employment and earnings. Our hypothesis is that localities experiencing relative declines in income and economic activity due to trade will also experience relative declines in home values and tax revenues, and relative increase in demand for public services. Unless there are countervailing adjustments in other sources of revenue, such as intergovernmental transfers, this will result in

\footnotetext{
${ }^{6}$ For example, during the period we analyze, one of the localities that faced the largest increases in import competition from China was Providence, RI, a major manufacturer of toys and costume jewelery. Meanwhile, employment in areas such as Washington, DC (which specializes in government services) and New Orleans, LA and Orlando, FL (which specialize in tourism) were hardly affected by Chinese import competition.
} 
greater difficulty in providing local public services.

\subsection{Public Finances in Local Labor Markets}

A key component of our paper involves how localities fund public services. We begin by defining the concept of a locality as a commuting zone and then examine the main sources of revenue and expenditures by function.

\subsubsection{Commuting Zones}

In our analysis, a commuting zone is the geographic unit defining a local labor market (Tolbert and Sizer, 1996). We group counties characterized by strong commuting patterns into 722 commuting zones for the US using the concordances from Autor et al. (2013). The notion of commuting zones resembles metropolitan areas with the exception that it includes the entire mainland US (both urban and rural areas) and that it subdivides some larger metropolitan areas into smaller units based on residents' commuting patterns. We consider the commuting zone as the appropriate unit of analysis for three reasons. First, a commuting zone is designed to include an individual's place of employment and residence even if these are in different counties. This overlap between employment and residential locations ensures the impact of trade shocks on labor market outcomes, public finances, and public service outcomes collectively occur within the same unit of analysis. Second, using commuting zones helps circumvent issues of selective migration, for example, migration from cities to suburbs, that may influence the provision of public goods within specific jurisdictions but not on average across an entire commuting zone. Lastly, local public goods are provided by a variety of government entities such as cities, counties, and specially-created districts such as school districts or transit authorities. In using commuting zones, we take the aggregate of revenues and

expenditures for all of these local entities and focus on overall public service provision at the entire commuting zone level.

\subsubsection{Revenues}

Local governments in the US rely on locally generated revenues and intergovernmental transfers to fund public services. Panel A of Table 1 describes the revenue side of public finances for 1990 
and 2007 7 The majority of local government revenues are locally generated: on average, about $61 \%$ of total revenue at the local level is from own sources, with the remainder (39\%) coming from intergovernmental transfers ${ }^{8}$ Total revenue from own sources comes mostly from general revenue $(85 \%)$ or from other sources such as employee retirement contributions, liquor store sales, and utilities (15\%). Local taxes comprise the majority of general revenues (about 60\%), with property taxes being by far the most important component accounting for around $80 \%$ of total tax revenue (and $45 \%$ of general revenue from own sources). The remainder of general revenues comes from various charges, fines, fees, and other taxes (individual income taxes, general sales taxes, and specific excise taxes), which also tend to vary with local economic activity.

Since general revenues are highly dependent on local economic activity, a decline in local economic activity can depress revenues and strain local public finances. The link between revenues and economic activity is both direct and indirect. The direct link is associated with sales and income tax collection, which vary closely with economic activity. The indirect link is associated with property tax collection: a decline in economic activity implies lower employment and wages, which reduces local housing demand, suppresses housing prices, and thereby reduces property tax collection 9

\footnotetext{
${ }^{7}$ The data are sourced from Individual Government Finances and are aggregated to the commuting zone level. See the data appendix for detailed variable definitions and information on data construction.

${ }^{8}$ There is substantial heterogeneity in the importance of various revenue sources across juristictions in the US. As described in the next section, we estimate all specifications in first-differences to account for time-invariant heterogeneity across localities. We additionally include state- or region-specific time dummies to allow for state- or region-specific trends in public finance institutions. Nevertheless, the summary statistics and estimates reported in this paper should be viewed as reflecting the typical behavior of local governments as a useful benchmark that may not be representative of specific individual jurisdictions.

9 Lutz et al. (2010) highlight several channels through which the housing market impacts tax revenues. First is the property tax channel, which is a function of the value of real estate and the volume of real estate transactions. Given the high dependence of local revenues on property tax collection, even small changes in housing values can have large effects on revenue. It is possible, however, that policy makers adjust the effective tax rate to offset some or all of the decline in revenue. Observed changes in property tax collection therefore reflect the combined effects of changes in property values and local government tax policies. Lutz (2008) reports that policy makers offset about 60 percent of house price changes by adjusting the effective tax rate. This observation implies that as house prices decline, policy makers increase the effective tax rate (often by delaying downward adjustments in property assessments). The decline in property values also has a secondary effect on local revenues through its impact on consumption. Since housing is the most important component of wealth for many households, a relative decline in home values tends to suppress homeowners' perceived wealth and their consumption of goods and services, which further reduces local sales tax revenues. The recent literature on local public finance shows that declines in housing prices have a lagged effect on local property tax collections, but once a decline in local public revenues occurs, localities react by cutting expenditures. For evidence on the relationship between housing prices and local government budgets, see Lutz et al. (2010), Chernick et al. (2011), Alm et al. (2014), and Cromwell and Ihlanfeldt (2015).
} 
A decline in locally generated revenues results in a proportional decline in expenditures unless intergovernmental transfers compensate for the own-revenue loss. On average, intergovernmental transfers comprise about $40 \%$ of total local revenues. Transfers from the state are the largest component, accounting for $85 \%$ of all intergovernmental transfers, with the remainder coming from the federal government (8\%) and other local governments (7\%). There is substantial variation in the magnitude of transfers across localities and over time, with federal and state transfers apportioned based on formulas depending on a locality's population and poverty rates measured during census years (Suarez Serrato and Wingender, 2014). As such, any migration response or change in the share of poor in a locality following an income shock may result in an adjustment of transfers and provide some degree of buffer against the negative shock.

There are several reasons why the insurance provided via intergovernmental transfers from state and federal governments may be incomplete. First, since allocation formulas are not specifically based on changes in localities' own revenues or economic conditions, the adjustments in intergovernmental transfers are not automatic. This is especially the case in response to trade-induced income shocks for which there is no evidence of a significant migration response 10 Second, the ability of state governments to distribute funds is limited by their own revenue collection, which may be highly correlated with the revenue collection of their localities. For instance, localities in states that are not diversified in terms of industrial composition are less likely to receive transfers from the state government following a negative trade shock that also affects economic outcomes and revenues in the rest of the state. Third, some transfers from federal and state governments, for example, for education and highway maintenance, are dedicated to particular expenditure categories and cannot be re-allocated to different functions. As a result, the level of insurance the state or federal government provide against a negative shock could vary across expenditure items.

Overall, our information on local government finances suggests that funding of local services relies heavily on own revenues, which tend to fluctuate with local economic activity. While intergovernmental transfers can theoretically alleviate fiscal constraints, in practice, the extent that these transfers prevent a decline in expenditures following a decline in locally generated revenues may be fairly limited.

\footnotetext{
${ }^{10}$ See Table $\mathrm{A} 1$ replicated from $\overline{\text { Autor et al. }}(2013)$.
} 


\subsubsection{Expenditures}

In the bottom panel of Table 1, we summarize local public expenditures by major categories. Education comprises the largest expenditure category, accounting for approximately $45 \%$ of local government spending. Public safety, including police and fire protection, and transportation, including roads and transit subsidies, are each about six to seven percent of total expenditures. Government administration, public welfare and housing, and natural resource management respectively account for five, four and two percent of local spending. Utilities (water and gas supply, electric power, sewerage, and solid waste management) are about $13 \%$ of total spending ${ }^{11}$ The remaining expenditures are on government-run liquor stores, insurance, ports and airports, and items that are classified as "other and unallocable". On average, spending shares across these categories remained fairly constant between 1990 and 2007.

While the majority of local government revenue is locally generated, it is possible that particular local public services are disproportionately funded by state and federal governments. For the key categories described in the bottom panel of Table 1, 36\% of total education expenditures, $57 \%$ of transportation expenditures, and $42 \%$ of public welfare expenditures come from locallygenerated revenue, with the remainder coming from intergovernmental transfers. Transfers from state governments represent almost all of the remaining revenues used to fund local education and transportation, while remaining revenues used to fund local welfare programs come nearly evenly from state and federal governments. For the other expenditure categories in the bottom panel of Table 1, we do not have a detailed breakdown of revenue sources, however, we note that just education, transportation, and welfare account for $86 \%$ of all state transfers and $64 \%$ of all federal transfers to localities. The importance of state transfers, especially for education, underscores our rationale for examining the ability of states to smooth local revenue shocks despite the fact that these transfers are unlikely to be very responsive to changing local economic conditions.

\subsubsection{Demand for Locally Provided Services}

In analyzing the effect of trade shocks on public service outcomes, there are two considerations. First, as discussed earlier, by reducing local revenues and expenditures, an increase in import

\footnotetext{
${ }^{11}$ Utilities, unlike other government services, are mostly funded by direct charges and fees rather than general taxation. Local government balance sheets include a line-item for revenue from utilities, and utility revenues and expenditures are extremely correlated $(\rho=0.98)$.
} 
competition may negatively affect the provision of local public services. Second, trade shocks may affect the demand for these services. As incomes decline, there may be greater dependence on local governments for services such as public education, transportation, public safety, welfare, and housing $\sqrt{12}$ For example, a decline in incomes and an increase in unemployment and poverty are associated with higher property crime rates 13 Similarly, as employment prospects for low-skilled workers decline, there is evidence that demand for education increases: students remain in school longer to acquire more skills 14 For public transport, welfare, and housing, there is again evidence that these services are more heavily used by lower-income residents, suggesting that as local incomes decline, demand for these services is likely to increase (Glaeser et al., 2008; Katz et al., 2001, Olsen and Barton, 1983).

\subsection{Local Outcomes and Public Finances}

In Table 2 we provide summary statistics for measures of income, home values, local public finances, and selected public service outcomes across commuting zones 15 On average, per capita income increased and poverty rates declined during our sample period. Between 1990 and 2007, median values for owner-occupied housing increased from $\$ 66,000$ to nearly $\$ 109,000$ in real terms. Total locality revenues per capita were $\$ 2,567$ in 1990 , increasing to $\$ 3,871$ by 2007 , with expenditures closely tracking these changes. Similar increases are evident for education expenditures per school age child, which rose from $\$ 5,471$ in 1990 to $\$ 8,983$ in 2007 in real terms, with these increases being associated with a reduction in student-teacher ratios, from 16.6 students per teacher in 1990

\footnotetext{
${ }^{12}$ According to Boustan (2013), a decrease in the share of rich households can make areas even less attractive to remaining households by reducing the size of the tax base and altering local electorate preferences for public services. Relatedly, Boustan et al. (2013), find that income inequality may be beneficial to the funding of local public goods, with high-income individuals disproportionately paying for and subsidizing services for the rest of the local population.

${ }^{13}$ An extensive literature links rising unemployment, higher poverty, and declines in wages for low-wage workers to increases in property crimes, with little or no change in violent crimes (Machin and Meghir, 2004, Raphael and Winter-Ebmer, 2001).

${ }^{14}$ For evidence of this link between education demand and employment prospects, see Greenland and Lopresti (2015) and Foster and Rosenzweig (1996).

${ }^{15}$ For our analysis, we supplement data from the Individual Government Finances with data from the County Business Patterns Database, the Census Integrated Public Use Micro Samples, and the American Community Survey. We also rely on replication data from Autor et al. (2013), which were made available via the website of the American Economic Review at dx.doi.org/10.1257/aer.103.6.2121. A detailed description of these data sources and construction of variables is provided in the appendix.
} 
to 14.2 in $2007{ }^{16}$ During this period, property crimes decreased from 33.5 in 1990 to 25.9 per 1,000 persons in 2007.

In Figure 1 we document the strong association between income, home values, public finances, and public good provision across commuting zones. Income per capita in a locality is positively associated with home values. Both lower income per capita and lower home values are associated with lower local government revenue per capita. Localities that collect less revenue per capita also tend to have lower per capita expenditures, with a nearly one-to-one relationship. Localities that spend less per person also spend less on education per student, and lower spending per student is associated with higher student-to-teacher ratios. Finally, there is only a weak relationship between per capita local government expenditures and crime.

While helpful in motivating the intuition for our paper, Figure 1 also highlights the need for exogenous variation in incomes across localities to establish causality for the association between income changes, housing values, local public finances, and local public good provision. For example, we propose that the association among local incomes, government revenue, and expenditures is due to shocks to income that affect home values and tax collection and thereby influence resources available for funding public services. A possibility, however, is that causation flows in the opposite direction: high-quality public goods are expensive and require more tax collection, and wealthy households value these goods and are willing to pay more for them, and so they select into more expensive commuting zones where such services are well-provided. To estimate a causal relationship, we need exogenous changes in local area incomes.

\section{Empirical Framework}

Our estimation strategy of deriving a causal relationship between trade-induced income shocks, local public finance, and service outcomes is based on the empirical framework developed in $\mathrm{Au}-$ tor et al. (2013). In this section, we introduce the instrumental variable approach for our main specifications and briefly discuss possible threats to identification.

\footnotetext{
${ }^{16}$ Student-teacher ratios differ from class sizes. To calculate student-teacher ratios, we use information on the total number of public school students and the total number of full-time equivalent teachers employed in public schools in a commuting zone. The data used to calculate this ratio includes teachers who are not necessarily involved in classroom instruction (e.g., teachers who also serve as administrators, substitute teachers, and teachers' aides who are certified as teachers).
} 


\subsection{Trade-Induced Shocks to Local Labor Markets}

We use a measure of exposure over time to Chinese imports at the commuting zone level as the source of variation in employment and incomes. We construct this measure as the change in US imports of Chinese goods per worker in a locality, using the share of each commuting zone in national industry employment as weights:

$$
\Delta I P W_{u i t}=\sum_{j} \frac{L_{i j t}}{L_{u j t}} \frac{\Delta M_{u c j t}}{L_{i t}} .
$$

In equation 1, $L_{i j t}$ is initial employment in commuting zone $i$ in sector $j$ for time period $t, L_{u j t}$ is initial total employment in the US in sector $j$ for time period $t, \Delta M_{u c j t}$ is the overall change in the value of US imports from China in sector $j$, and $L_{i t}$ is initial total employment in commuting zone $i{ }^{17}$ The expression in equation (1) apportions the change in the value of US imports from China in a specific industry depending on how employment in that industry is initially distributed across commuting zones in the US and then rescales this value by total commuting zone employment.

To further motivate our analysis, Table 3 depicts changes in incomes and local outcomes for commuting zones experiencing the smallest and largest changes in Chinese import competition per worker between 2000 and 2007. For the most negatively affected (top quartile) of commuting zones, the average increase in Chinese imports per worker was $\$ 4,310$, while it was only $\$ 243$ for commuting zones that were hardly affected (bottom quartile). Average household income declined by approximately $1.6 \%$ for commuting zones in the top quartile but increased by nearly $8 \%$ for commuting zones in the bottom quartile. Poverty rates increased by 2.4 percentage points in the top quartile but declined by 0.4 percentage points in the bottom quartile. While housing values increased in both groups of commuting zones, they increased by substantially more among those in the bottom quartile. The same pattern holds for changes in total locality revenues and expenditures: they increased by more in localities less affected by trade shocks. While education expenditures per student also increased overall, they did so to a greater extent in localities less exposed to Chinese import competition, and a corresponding pattern holds for student-to-teacher ratios: they declined slightly more in localities in the bottom quartile. Finally, while property

\footnotetext{
${ }^{17}$ This variable, $\triangle I P W_{\text {uit }}$, is constructed in Autor et al. (2013) using the UN Comtrade Database for measures of Chinese imports at the six-digit product level and the County Business Patterns Database for manufacturing employment in each US county (concorded to commuting zones) by four-digit SIC code. See the data appendix for further information.
} 
crimes increased slightly (by 2.7\%) among localities in the top quartile, they declined substantially (by $21.4 \%$ ) among localities least exposed to Chinese import competition.

\subsection{Endogeneity of Trade-Induced Shocks}

One concern in identifying a causal relationship between US imports of Chinese goods and local outcomes across US commuting zones is that industry level demand shocks in the US might be correlated with imports from China, implying, in other words, that changes in US incomes could be driving changes in US imports per worker 18 The alternative we emphasize is that growth in US imports of Chinese goods was primarily due to structural reforms within China that led to a surge of Chinese imports into the US. To capture this exogenous variation in imports, we use the change in other high-income country imports of Chinese goods, $\triangle I P W_{\text {oit }}$, as an instrument for US changes in imports per worker, as in Autor et al. (2013). The instrument, $\Delta I P W_{\text {oit }}$, is calculated as follows:

$$
\Delta I P W_{o i t}=\sum_{j} \frac{L_{i j t-1}}{L_{u j t-1}} \frac{\Delta M_{o c j t}}{L_{i t-1}} .
$$

The expression in equation (2) uses employment levels by industry and region from prior decades and uses the change in the value of other high-income countries' imports of Chinese goods in each sector $\left(\Delta M_{o c j t}\right)$. The use of lagged employment levels mitigates the possibility that employment is contemporaneously adjusting to anticipated Chinese trade and the use of other high income countries' imports of Chinese goods, as opposed to US imports of these goods, circumvents the possibility that demand factors in the US were simultaneously driving both the surge in Chinese imports and the changes in the outcome variables we consider.

The identification strategy relies on the assumption that the variation in the instrumental variable is supply-driven and due to a combination of a fall in trade costs and improvements in China's comparative advantage in specific sectors. Autor et al. (2013) discuss three possible threats to identification: correlated product demand shocks across high-income countries, an increase in high-income country imports from China due to a negative productivity shock in the US, and common technological developments in high-income countries (e.g. automation) that drive the

\footnotetext{
${ }^{18}$ For example, US imports of specific goods from China could be increasing because US demand for these goods is increasing overall. This would potentially imply an increase in both Chinese imports and US production of these goods, which would then benefit the commuting zones that specialize in producing these goods.
} 
increase in imports from China. They rule out the first by estimating a modified gravity model designed to isolate changes in China's exports driven solely by supply and trade shocks. While they cannot explicitly rule out the latter two possibilities, they argue that forces internal to China are likely the dominant factors explaining the Chinese export surge, which greatly outpaced that of other low- and middle-income nations during this period.

\subsection{Main Specifications}

We estimate the effects of changes in Chinese imports per worker on local public finances and the provision of public goods using the following equation:

$$
\Delta Y_{i t}=\gamma_{t}+\beta_{1} \Delta I P W_{u i t}+X_{i t}^{\prime} \beta_{2}+\varepsilon_{i t}
$$

In equation (3), $\Delta Y_{i t}$ is the change in the local outcome variable in commuting zone $i$ calculated over two time periods, 1990-2000 and 2000-2007. The latter period is rescaled so as to capture tenyear equivalent changes. The main local outcomes we consider are the level and distribution of household incomes, median housing values, total government revenues, revenues by source (e.g., locally generated revenues from taxes and fees, intergovernmental transfers), and local government expenditures. Changes in the provision of local public services are measured using changes in expenditures for each public service item (e.g., education, transportation, public safety, public welfare, public housing, parks and natural resources, and government administration) and more direct measures of changes in public service outcomes, when data are available, in the case of public safety (property and violent crime rates) and public education (student-teacher ratios).

Each specification is estimated using two-stage least squares (2SLS) by instrumenting the change in US imports per worker of Chinese goods in commuting zone $i\left(\Delta I P W_{\text {uit }}\right)$ with the change in other high-income countries' imports of Chinese goods $\left(\triangle I P W_{\text {oit }}\right)$. First differencing controls for locality characteristics that may influence the outcome variables but are fixed over time. Each specification includes decade fixed-effects $\left(\gamma_{t}\right)$ and locality controls capturing start-of-period demographic characteristics and labor force composition $\left(X_{i t}\right)$, which might independently influence the outcome variables. Specifically, we include the share of employment in manufacturing, the share of the population that is college educated, the share of the population that is foreign-born, the share of women in the workforce, the share of routine occupations in employment, and the average offshorability index of occupations. Our main specification includes geographic dummies for the 
nine census divisions to absorb any region-specific trends in variables of interest; we also experiment with using state fixed-effects in Section 5. Standard errors are clustered at the commuting zone level 19

We are also interested in examining the ability of larger and more economically diverse states to smooth local government finances via intergovernmental transfers. This is important since, on average, about forty percent of revenues at the commuting zone level comes from intergovernmental transfers, and $85 \%$ of these transfers are from state governments. In testing for state-level smoothing, we first modify equation (3) to replace the trade exposure measure at the commuting zone level with a measure at the state level. Then we estimate the separate impact of an increase in trade exposure at the commuting zone level and in the rest of the state using the following equation:

$$
\Delta Y_{i t}=\gamma_{t}+\gamma_{1} \Delta I P W_{u i t}+\gamma_{2} \Delta I P W_{u t, s-i}+X_{i t}^{\prime} \gamma_{3}^{\prime}+u_{i t}
$$

where the only difference from equation (3) is the inclusion of $\Delta I P W_{u t, s-i}$, which reflects the change in imports per worker in the remainder of the state.

\section{Results}

In this section, we present our findings on the impact of increased Chinese import competition on local public finances and service provision. The coefficient estimates we report represent the differential effect of imports across localities that are more exposed to Chinese competition relative to those that are less exposed. In discussing the magnitudes of our findings, we evaluate all coefficient estimates for a $\$ 1000$ increase in Chinese imports per worker. This value corresponds approximately to the interquartile difference for the change in Chinese imports per worker across localities between 2000 and 2007. In other words, we are examining differences in local public finances and service provision in highly exposed commuting zones relative to those that face little competition from Chinese imports.

\footnotetext{
${ }^{19}$ To the extent that states can smooth local outcomes, clustering at the state level in our main specification actually yields smaller standard errors. We therefore report standard errors clustered at the commuting zone level, which are more conservative, but show, in Section 5 , that our main results hold with clustering at the state level.
} 


\subsection{Population Composition, Employment, and Incomes}

The starting point of our empirical analysis is two key findings from Autor et al. (2013). First, an increase in import exposure does not result in a reallocation of workers across commuting zones: localities that are differentially exposed to trade shocks do not experience a differential change in total population or a differential change in the skill composition of the population ${ }^{20}$ This finding, which we replicate in Table A1, is important to our analysis as it suggests that a local trade shock does not quickly diffuse across localities in the US via labor mobility; workers do not out-migrate (neither as a whole, nor differentially) from areas that experience trade-induced income shocks to arbitrage wage and quality-of-life differentials across localities. Second, an increase in exposure of local labor markets to Chinese imports leads to a significant decline in employment and earnings in these localities. In Table 4. Panel A, we replicate this finding from Autor et al. (2013). An increase of $\$ 1000$ per worker in a commuting zone's import exposure results in a 0.22 percentage point increase in the unemployment rate and a 0.55 percentage point increase in the share of the population that is not in the labor force. The increase in exposure results in a relative decline in average household incomes by $1.48 \%$ (or about $\$ 492$ per working age adult per year). While transfer incomes increase in response (by $2.11 \%$, which amounts to only $\$ 17$ per year), this increase does not offset the decline in wage and salary incomes (of $2.14 \%$, which amounts to $\$ 549$ per year).

As discussed earlier, an increase in trade exposure could impact local government size and the provision of public services through its impact on the mean level of income in a locality as well as through its impact on the distribution of local income. If, for example, an increase in competition from China results in an increase in the share of low-income households, this could amplify the financial constraints faced by localities by raising demand for public services while reducing the tax base. Our findings reported in Panel B of Table 4 provide evidence that this is indeed the case. We find that higher trade exposure is associated with a relative increase in the share of the population living in households with annual incomes less than $\$ 30,000$ (in nominal US\$) and a decline in the share of the population living in households with annual incomes above $\$ 60,000$; the relative decline in the share of households with annual incomes between $\$ 30,000$ and $\$ 60,000$, is

\footnotetext{
${ }^{20}$ This finding coincides with Topel (1986), Blanchard and Katz (1992), and Glaeser and Gyourko (2005) who similarly find that mobility responses to labor demand shocks across US localities are slow and incomplete. It differs from Bound and Holzer (2000) and Notowidigdo (2011) who report changes in population composition due to differential mobility patterns.
} 
small and statistically insignificant. Moreover, an increase in trade exposure leads to an increase in poverty rates, especially for households with children, which are particularly dependent on public assistance.

\subsection{Home Values and Business Activity}

Our hypothesis is that the observed decline in the number of employed workers and household incomes, together with an increase in the share of low-income households, results in a relative decline in the tax base and higher demand for public services among localities more exposed to import competition. We test a subset of this hypothesis by focusing on property values and business activity as one of the channels through which trade with China could impact local public finances. This is an important channel as more than half of locally generated general revenue is from local taxes, with property taxes accounting for about $80 \%$ of total tax revenue.

We start by examining whether the deterioration in economic outcomes in localities that are differentially impacted by trade with China results in a relative decline in home values. In column (1) of Table 5, we report estimates from specification 3 with ten-year changes in the median value of owner-occupied housing units as the dependent variable ${ }^{21}$ We find that a commuting zone with an increase of $\$ 1000$ in Chinese imports per worker experiences lower median housing values by $5.4 \%$ (column 1) or about $\$ 7,660$ (column 2). This finding is consistent with a relative decline in household incomes and housing demand. We find the relative decline in the value of housing to be driven by an increase in the share of homes valued between $\$ 150,000$ and $\$ 300,000$ and a decrease in the share of homes valued above $\$ 300,000$.

The median housing values for owner-occupied units are based on self-reported values, which

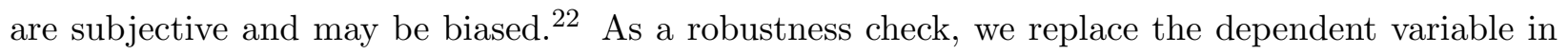
specification 3 with changes in the annual median contract rents of renter-occupied units. The reporting error in monthly rents is likely to be smaller, and housing values and rental prices are highly correlated. Estimates reported in columns (6) and (7) are in line with our findings for

\footnotetext{
${ }^{21}$ We use information on median self-reported home values for owner-occupied housing from the Census of Population and Housing as a proxy for assessed property values, which is the base for property taxation. While the changes in assesed values are correlated with changes in market values, note that re-assesments are not automatic and may involve lags.

${ }^{22}$ Although there is some evidence that self-reported home values (in levels) may be an overestimate of sales values (Kiel and Zabel 1999), these biases are likely to be smaller in our case, as we focus on decadal changes in housing values (Skinner, 1994).
} 
owner-occupied units: a $\$ 1000$ increase in a commuting zone's import exposure per worker results in a relative decline of $2.5 \%$ in median rents in the commuting zone or about $\$ 187$ on an annualized basis 23

Businesses also typically pay local property taxes and contribute to local revenue generation through sales taxes, licenses, and fees. While data limitations prevent us from separately analyzing the impact of trade shocks on commercial and industrial real estate values $\sqrt{24}$ we use information from County Business Patterns data on the number and size of business establishments in each commuting zone to highlight the likely impact of import competition on revenue generated from local business. In Table 6, we report the change in the total number of establishments due to an increase in Chinese import exposure. While the coefficient estimate on the total number of establishments is negative, it is not significant (column 1). We also do not find any significant effect on the number of small establishments, i.e., those with fewer than 50 employees (column 2). However, we find significant declines in the number of medium and large establishments, those with 50 to 499 employees and those with more than 500 employees (columns 3 and 4). A $\$ 1000$ increase in a commuting zone's import exposure per worker results in a relative decline of approximately $1.9 \%$ and $2.9 \%$, respectively, in the number of medium and large establishments. We interpret these declines in the number of medium and large establishments, coupled with the preceding information on local employment, as suggestive of declines in local economic activity with negative implications for local government revenues.

\subsection{Local Government Size}

Next we examine whether areas more exposed to Chinese import competition experience a differential change in local government size. Our estimation results are reported in Table 7 for revenues and in Table 8 for expenditures. In all specifications, revenues and expenditures are calculated in per capita terms. The top and bottom panels in each table respectively report the

\footnotetext{
${ }^{23}$ We also conduct robustness checks at the state level where we have information on mean (as opposed to median) housing prices recorded as an index based on several different sources of data (Enterprise, FHA, and Real Property County Recorder Data Licensed from DataQuick). The estimate based on state-level house price indices suggests that mean housing prices in a state decline with exposure to trade shocks [coefficient estimate (standard error) of -1.544 (0.343) on the change in Chinese imports per worker variable, not reported in Table 5. The decline in mean prices relative to less affected states suggests that trade shocks do not simply lead to a mean-preserving change in the distribution of housing prices.

${ }^{24}$ Gyourko (2009) find the commercial and housing real estate sectors to exhibit similar time series patterns with a simple correlation between the appreciation rates in two sectors of nearly $40 \%$.
} 
impact of a change in Chinese imports per worker in percent changes (the dependent variable being changes in log values) and in dollar amounts (the dependent variable being changes in absolute values). While per capita changes in dollar amounts are informative, we focus our discussion on results calculated in percent changes since the benefits from most public good categories we study are unevenly distributed across the population.

Our results in Table 7 suggest that total revenues per capita decline by $1.9 \%$ for every $\$ 1000$ increase in Chinese imports per worker (column 1). On average, intergovernmental transfers remain unchanged (column 2); almost all of the decline in total revenues is from a decrease in local revenue from own sources, which decline by $2.9 \%$ (column 3 ). While the finding on intergovernmental transfers is broadly consistent with the lack of significant population changes in response to a negative trade shock, it is possible that the average effect masks heterogeneity across localities in states which differ in their ability to smooth shocks. We explore this possibility in Section 4.5 .

Both sources of locally generated revenue, namely, general revenue (column 4) and revenue from other sources (column 10), are lower in localities that experience larger trade shocks ${ }^{25}$ Almost all of the decline in general revenue from own sources is from a decline in total tax revenue (by $1.7 \%$ for every $\$ 1000$ increase in Chinese imports, shown in column 5), with this decline nearly evenly split in absolute values between declines in property tax revenue (column 6) and declines in local sales, income, and vehicle taxes (column 7). The estimated declines in revenues from other taxes (column 8) and miscellaneous fines and charges (column 9) are small and statistically indistinguishable from zero.

As expected, changes in local expenditures per capita closely track changes in local revenues per capita. As shown in Table 8, total expenditures per capita (column 1) decline by nearly $1 \%$ for every $\$ 1000$ increase in Chinese imports, which is very close in absolute magnitude to

\footnotetext{
${ }^{25}$ Although we report the estimation results for the sub-category of revenues from other sources that includes revenues from liquor stores, utilities, and employee retirement contributions, we treat these findings with caution for several reasons. First, revenues from public employee retirement contributions include earnings on investments and unrealized gains or losses on cash and security holdings that are subject to market variation. While the market variation in these holdings may be similar across commuting zones, we hesitate to attribute any changes in revenues from employee retirmement contributions to changes in the number of public employees or to the amounts they are contributing. Second, more than half of the commuting zones do not report positive values for the three categories that make up other sources of revenues and therefore the changes in this component could be driven by a small number of commuting zones. Finally, these revenues tend to be earmarked, for example, they include utility payments intended to cover the costs of operating local utilities and retirement contributions intended to cover future employee retirement costs. They are therefore separate from revenues intended to cover current local government operations.
} 
the decline in general revenue from own sources ( $\$ 44$ versus $\$ 48$ per capita). The breakdown of expenditures by public service category uncovers interesting heterogeneity in the effects of exposure to Chinese imports. We find that all major expenditure categories, with the exception of public safety, experience varying declines following an increase in Chinese imports.

Specifically, while the relative decline in per capita education expenditures (of nearly 1\%, shown in column 2) is proportional to the relative decline in total expenditures per capita, we find no differential impact in terms of public safety expenditures (column 3). This is despite the relative decline in incomes and increase in unemployment and poverty rates in these localities, which are all factors documented to be positively associated with higher crime rates. Spending on public welfare (column 4) and public housing (column 5) each decrease by about 7-8\%, and expenditures on local transport and utilities each decline by about 2-3\% in response to a $\$ 1000$ increase in Chinese import competition. The estimated spending impacts on government administration and parks and natural resources are also negative, although the coefficients are not statistically significant.

Our results suggest that expenditures on public services, especially those that disproportionately benefit low-income households (e.g. public welfare, public housing, and public transport), differentially change in commuting zones in the top quartile of the trade shock distribution relative to those in the bottom quartile. We interpret the relative decline in expenditures precisely at a time when the share of the poor in these localities is increasing as suggestive evidence of a deterioration of public service outcomes in these localities. For public education and public safety two expenditure items for which we have fairly good proxies for public service outcomes - we test whether the relative changes in outcome measures in response to an increase in imports are broadly consistent with such an interpretation of the expenditure results.

\subsection{Public Good Provision: Education and Crime}

In the case of public safety, our results in earlier sections suggest that while income and employment decreased in trade exposed localities, these localities did not increase public safety spending. Given the documented association between worsening economic outcomes and higher crime rates, the fact that public safety spending does not change suggests that crime rates are likely to increase. Estimates reported in the first two columns of Table 9 suggest this is the case: a $\$ 1000$ increase in Chinese imports per worker is associated with a relative increase in property crime rates by $3.5 \%$, 
with no significant effect on violent crimes (columns 1 and 2) 26

Similarly, we previously demonstrated that per capita spending on education differentially decreases in trade exposed localities. Our estimates suggest that a decline in education expenditures leads to higher student-teacher ratios (measured as total number of students to full-time equivalent teachers in column 3 and pre-kindergarten to twelfth grade students to full-time equivalent teachers in column 4). This is suggestive evidence that the decline in expenditures translates into a deterioration of public education services in these localities. Moreover, the relative decline in the quality of education services may be taking place precisely in localities where the demand for education appears to increase differentially. Specifically, Greenland and Lopresti (2015) document a relative decrease in high school dropout rates in response to an increase in imports from China, suggesting that students in these localities respond to a deterioration of employment prospects for low-skilled workers and a resulting increase in the relative returns to skill acquisition by remaining in school longer ${ }^{27}$ The implication is that demand for local public goods such as education and public safety is increasing at a time when funding and resources for these services are declining or remaining constant. We view these results for the quality of public safety and education as indicative of what might be happening to other public services, whose quality we cannot measure, as local government spending declines.

\subsection{State-Level Smoothing via Intergovernmental Transfers}

As discussed in Section 2.1, state governments provide local governments with a large share of funding for specific public goods such as education, transportation, and public welfare. In this section, we examine variation in states' abilities to provide a buffer for negative shocks faced by their local governments. We begin by testing how responsive public finance outcomes within commuting zones are to changes in trade exposure at the state level. In Table 10 , Panel A, we find that local revenues - total, own revenue, and intergovernmental transfers - decline as imports per worker in the state increase. State level exposure to trade is negatively associated with education

\footnotetext{
${ }^{26}$ These findings are consistent with Iyer and Topalova (2014) and Dix-Carneiro et al. (2015) who document, for India and Brazil, that negative shocks to income due to trade are associated with higher crime rates.

${ }^{27}$ In unreported results at the state level, in addition to a decline in high-school dropout rates (for both 16 to 19 year olds and 16 to 24 year olds), we find an increase in continuation rates to at least some college education for 19 to 24 year olds in states differentially exposed to trade. See also Foster and Rosenzweig (1996), who argue that workers respond to positive employment shocks in an industry requiring higher levels of skill by seeking out further investments in human capital.
} 
expenditures per capita, and commuting zones in states that experience an increase in Chinese import competition consequently report a relative deterioration of education quality as measured by student-teacher ratios. We find a similar negative association between state-level imports from China and spending on public welfare and housing.

Next we decompose the total effect of an increase in trade exposure into changes in own exposure at the commuting zone level and residual exposure at the state level. As shown in Table 10, Panel B, we find that total local revenue is more dependent on shocks to the commuting zone than on shocks to the remainder of the state. As expected, changes in revenues from own sources are entirely due to shocks at the commuting zone level whereas intergovernmental transfers decline substantially when the rest of the state experiences an adverse trade shock. Both local education expenditures per capita and expenditures on public welfare and housing per capita decline as imports per worker in the commuting zone increase, and they decline further as imports per worker in the remainder of the state increase. Rising imports per worker in both the commuting zone and in the remainder of the state are associated with higher student-teacher ratios, although only the effect at the commuting zone level remains significant when clustering errors by state.

These results suggest that state intergovernmental transfers can function as a mechanism to smooth local outcomes but only when commuting zones and the remaining areas of a state face different economic shocks. When both the commuting zone and the remaining areas of a state experience negative economic shocks, or in other words, when shocks at the commuting zone and remainder of state level are highly correlated ${ }^{28}$ then effects on local revenues, expenditures, and outcomes can become compounded.

\section{Extensions and Robustness}

In this section, we consider an extension of our empirical strategy using the change in Chinese exports to other high-income countries as an instrument for the change in average household earnings in US labor markets. Whereas our main results focus on the impact of trade, here we consider the direct effects of shocks to household earnings on local outcomes and use variation in trade shocks to estimate income elasticities for various local public finance outcomes. We also present

\footnotetext{
${ }^{28}$ We find this to be the case for the trade shock we consider: the increase in Chinese imports per worker at the commuting zone and at the rest of the state are correlated with $\rho=0.42$.
} 
several robustness checks to verify that our results are not due to pre-existing trends and are not overly sensitive to alternative specifications or methods of clustering.

\subsection{Income Shocks and Local Outcomes}

To assess the effects of income shocks on local outcomes, we estimate equation (3) where we replace $\Delta I P W_{\text {uit }}$, the change in US imports per worker of Chinese goods, with $\Delta$ ln avg. HH inc., the change in log average household incomes. All other variables including the instrument, $\Delta I P W_{\text {oit }}$ (the lagged change in other high-income countries' Chinese imports per worker), remain unchanged. Results are reported in Table 11 .

In Panel A of Table 11, we show the first-stage regression results. The coefficient estimate on $\triangle I P W_{\text {oit }}$ is negative and significant, suggesting that a rise in other high-income countries' Chinese imports per worker is associated with an eventual decline in average household earnings across US commuting zones exposed to Chinese manufacturing competition.

Panel B of Table 11 shows second-stage regression results suggesting that an increase in household incomes results in higher housing values, higher local revenues, higher local expenditures, and better public good outcomes. Our point estimates suggest that a $1 \%$ decline in household incomes due to trade shocks leads to a $3.7 \%$ decline in property values, a $1.3 \%$ decline in total local revenue per capita, a $2.0 \%$ decline in total own revenue per capita, a $0.6 \%$ decline in total local expenditures per capita, a $0.59 \%$ decline in total education expenditures per capita, a $2.9 \%$ increase in property crime rates, and an increase of 0.14 students per teacher 29 These results provide suggestive evidence of how exogenous changes to local incomes affect local housing prices, finances, and public good outcomes.

\subsection{Robustness}

A potential explanation for the results we observe is that omitted locality characteristics jointly determine changes in local outcomes as well as changes in Chinese imports per worker. This might

\footnotetext{
${ }^{29}$ To calibrate these magnitudes relative to our previous findings, it is worth recalling that a $\$ 1000$ increase in Chinese imports per worker is associated with a $1.48 \%$ decline in average household incomes. Multiplying the coefficient estimates of Table 11. Panel B, by -1.48 yields the same magnitudes as obtained in previous tables where the variable of interest was the change in Chinese imports per worker. For the property crime sample with information on 568 commuting zones, the change in average household incomes corresponding to a $\$ 1000$ increase in Chinese imports per worker is $-1.20 \%$; multiplying the coefficient estimate on property crimes by -1.20 yields the same coefficient estimate as obtained in Table 9
} 
be the case, for example, if declining localities also happen to be more vulnerable to Chinese import competition.

To examine this possibility, we experiment with several robustness checks and placebo tests, the results of which are shown in Table 12. For reference, we show in column (1) the base case results from estimating equation (3) for several of our main dependent variables. In column (2), we include as a regressor the 1980-1990 value of the dependent variable as a way of controlling for pre-existing trends. None of the coefficient estimates for the change in current Chinese imports for any of our main dependent variables are significantly different from the base case. In column (3), we instrument for the 1980-1990 values of the dependent variable using 1980 levels of the dependent variable ${ }^{30}$ The coefficient estimates for the change in current period Chinese imports per worker remain similar to our base case estimates, although standard errors become larger. As a placebo check, we regress our main dependent variables calculated over 1980-1990 (the pre-period) on future Chinese import exposure, calculated as the average between 1990-2000 and 2000-2007. We report estimates from specifications without any locality controls in column 4 and with only census region fixed effects in column 5. None of the coefficient estimates on future Chinese imports per worker are significant except for the ones on the change in total locality expenditures per capita, suggesting, if anything, that areas with rising per capita expenditures (not declining per capita expenditures) were the ones eventually more exposed to Chinese import competition. These results suggest that the potential bias, to the extent any exists, works against our main findings. Importantly, these robustness checks and placebo tests indicate that pre-existing trends in our dependent variables are unlikely to be driving our results 31

To gauge sensitivity of our estimates to alternative specifications and clustering, we experiment with replacing region fixed-effects with state fixed-effects, clustering at the state rather than commuting zone level, omitting all locality-level controls except state and time fixed-effects, and

\footnotetext{
${ }^{30}$ Our dependent variables are stacked first differences covering two periods, 1990-2000 and 2000-2007. By also including a control variable that captures changes during the 1980-1990 period, we are potentially introducing a mechanical bias and contaminating all of our coefficient estimates since 1990 values now appear on both sides of the equation. We attempt to address this problem by instrumenting for 1980-1990 changes using 1980 levels of our dependent variables.

${ }^{31}$ For student-teacher ratios, we do not have data prior to 1990 and cannot test for pre-existing trends. When conducting the placebo tests (columns 4 and 5), we no longer have stacked first differences: data for the dependent variables are for one period only, 1980-1990 (the pre-period), while the change in future Chinese imports per worker is calculated as the average of the changes between 1990-2000 and 2000-2007 (the future periods).
} 
excluding potential outlier states such as California, which limits property tax collection. All of our results hold. We report these additional robustness checks for select variables in the appendix. 32

\section{Conclusion}

There has recently been increased interest in the localized effects of trade and income shocks and on the ability of individuals to out-migrate from negatively affected areas in order to arbitrage away quality-of-life differences. While the literature had previously emphasized labor mobility as a means of maintaining parity in locational preferences (Rosen, 1979, Roback, 1982), recent empirical research suggests that labor mobility is slow and incomplete (Topel, 1986; Blanchard and Katz, 1992 Glaeser and Gyourko, 2005), and that the costs and benefits of national policies like trade liberalization are therefore unequally distributed across localities.

We contribute to this literature by showing that trade-induced income shocks constrain local resources and lead to a relative deterioration in the quality of local public goods. Since high-skilled workers and new growth industries tend to value high quality public goods (Black, 1999 ; Moretti, 2012), the fact that areas negatively affected by trade shocks face greater difficulty in providing these goods makes it more challenging for them to compete economically against other localities and recover from shocks.

The results of this paper, in tracing out how trade and income shocks can ultimately affect local public services, constitute an important input to the design of government policies. Trade assistance programs and intergovernmental transfers are currently insufficient to arrest the declines in incomes and public service quality in localities negatively affected by trade liberalization. At the same time, an array of policies makes it more difficult for workers, especially low-skilled workers, to migrate to more economically vibrant areas (Glaeser, 2011). The consequence is greater disparity both in incomes and in the quality of essential public services across the US, suggesting a potential for welfare enhancing government interventions to either equalize opportunities or reduce barriers to migration across localities.

\footnotetext{
${ }^{32}$ We also re-ran our estimations excluding one state at a time. Our results are not sensitive to individual states.
} 


\section{References}

Alm, J., Buschman, R. D., Sjoquist, D. L., 2014. Foreclosures and local government revenues from the property tax: The case of Georgia school districts. Regional Science and Urban Economics $46,1-11$.

Autor, D., Dorn, D., Hanson, G. H., 2013. The China syndrome: Local labor market impacts of import competition in the United States. American Economic Review 103 (6), 2121-2168.

Bartik, T. J., 1991. Who benefits from state and local economic development policies? W.E. Upjohn Institute for Employment Research, Kalamazoo, MI.

Baum-Snow, N., Ferreira, F., October 2014. Causal inference in urban and regional economics. Working Paper 20535, National Bureau of Economic Research.

Black, S. E., 1999. Do better schools matter? Parental valuation of elementary education. Quarterly Journal of Economics 114 (2), 577-599.

Blanchard, O., Katz, L. F., 1992. Regional evolutions. Brookings Papers on Economic Activity $23(1), 1-76$.

Bound, J., Holzer, H. J., 2000. Demand shifts, population adjustments, and labor market outcomes during the 1980s. Journal of Labor Economics 18 (1), 20-54.

Boustan, L., 2013. Local public goods and the demand for high-income municipalities. Journal of Urban Economics 76, 71-82.

Boustan, L., Ferreira, F., Winkler, H., Zolt, E., 2013. The effect of rising income inequality on taxation and public expenditures: Evidence from US municipalities and school districts, 19702000. Review of Economic Studies 95 (4), 1291-1302.

Cerny, P. G., 1995. Globalization and the changing logic of collective action. Industrial Organization 49 (4), 595-625.

Chernick, H., Langley, A., Reschovsky, A., 2011. The impact of the Great Recession and the housing crisis on the financing of America's largest cities. Regional Science and Urban Economics 41 (4), $372-381$. 
Cromwell, E., Ihlanfeldt, K., 2015. Local government responses to exogenous shocks in revenue sources: Evidence from Florida. National Tax Journal 68 (2), 339-376.

Davidson, C., Matusz, S., 2004. International Trade and Labor Markets: Theory Evidence and Policy Implications. W. E. Upjohn Institute for Employment Research.

Dix-Carneiro, R., Soares, R. R., Ulyssea, G., September 2015. Local labor market conditions and crime: Evidence from the Brazilian trade liberalization. Working Paper.

Feenstra, R., Hanson, G. H., 2002. Global production and inequality: A survey of trade and wages. In: Choi, E, K., Harrigan, J. (Eds.), Handbook of International Trade. Basil Blackwell.

Foster, A. D., Rosenzweig, M. R., 1996. Technical change and human capital returns and investments: Evidence from the Green Revolution. American Economic Review 86 (4), 931-953.

Glaeser, E. L., 2011. Triumph of the City. Penguin US, New York.

Glaeser, E. L., Gyourko, J., 2005. Urban decline and durable housing. Journal of Political Economy $113(2), 345-375$.

Glaeser, E. L., Kahn, M. E., Rappaporte, J., 2008. Why do the poor live in cities? The role of public transportation. Journal of Urban Economics 63 (1), 1-24.

Goldberg, P., Pavcnik, N., 2007. Distributional effects of globalization in developing countries. Journal of Economic Literature 45 (1), 39-82.

Greenland, A., Lopresti, J., March 2015. The good news about disappearing jobs: US high school graduation rates and import exposure. Working Paper.

Gyourko, J., 2009. Understanding commercial real estate: Just how different from housing is it?, NBER WP 14708.

Hakobyan, S., McLaren, J., November 2010. Looking for local labor market effects of NAFTA, NBER WP 16535.

Harrison, A., 2007. Globalization and Poverty. University of Chicago Press. 
Iyer, L., Topalova, P. B., 2014. Poverty and crime: Evidence from rainfall and trade shocks in India, Harvard Business School BGIE Unit Working Paper No. 14-067.

Katz, L. F., Kling, J. R., Liebman, J. B., 2001. Moving to opportunity in Boston: Early results of a randomized mobility experiment. Quarterly Journal of Economics 116 (2), 607-654.

Kiel, K. A., Zabel, J. E., 1999. The accuracy of owner-provided house values: The 1978-1991 American Housing Survey. Real Estate Economics 27 (2), 263-298.

Kovak, B., 2013. Regional efects of trade reform: What is the correct measure of liberalization? American Economic Review 103 (5), 1960:1976.

Krebs, T., Krishna, P., Maloney, W., 2010. Trade policy, income risk, and welfare. The Review of Economics and Statistics $92(3), 467-481$.

Krishna, P., Senses, M. Z., 2014. International trade and labor income risk in the United States. Review of Economic Studies 81 (1), 186-218.

Lutz, B., Molloy, R., Shan, H., 2010. The housing crisis and state and local government tax revenue: Five channels, finance and Economics Discussion Series 2010-49, Federal Reserve Board.

Lutz, B. F., 2008. The connection between house price appreciation and property tax revenues. National Tax Journal 61 (3), 555-572.

Machin, S., Meghir, C., 2004. Crime and economic incentives. Journal of Human Resources 39 (4), 958-979.

McLaren, J., Newman, A., 2002. Globalization and insecurity. Working Paper 02-06, University College London, Department of Economics London.

McManus, T., Schaur, G., August 2015. The effects of import competition on health in the local economy, Working Paper.

Moretti, E., 2012. The New Geography of Jobs. Houghton Mifflin Harcourt, New York.

Newbery, D., Stiglitz, J., 1984. Pareto-inferior trade. Review of Economic Studies 51 (1).

Notowidigdo, M., 2011. The incidence of local labor demand shocks, NBER WP 17167. 
Olsen, E. O., Barton, D. M., 1983. The benefits and costs of public housing in New York City. Journal of Public Economics 20 (3), 299-332.

Raphael, S., Winter-Ebmer, R., 2001. Identifying the effect of unemployment on crime. Journal of Law and Economics 44 (1), 259-283.

Roback, J., 1982. Wages, rents, and the quality of life. Journal of Political Economy 90 (6), $1257-$ 1278.

Rodrik, D., 1997. Has Globalization Gone Too Far? Institute for International Economics.

Rodrik, D., 1998. Why do more open economies have bigger governments? Journal of Political Economy 106 (5), 997-1032.

Rosen, S., 1979. Wages-based indexes of urban quality of life. In: Mieszkowski, P., Straszheim, M. (Eds.), Current Issues in Urban Economics. Johns Hopkins University Press.

Sachs, J. D., 2011. The Price of Civilization: Reawakening American Virtue and Prosperity. Random House.

Senses, M. Z., 2010. The effects of offshoring on the elasticity of labor demand. Journal of International Economics 81 (1), 89-98.

Skinner, J., 1994. Housing and saving in the United States. In: Noguchi, Y., Poterba, J. M. (Eds.), Housing Markets in the United States and Japan. University of Chicago Press, Chicago, IL, pp. $191-213$.

Slaughter, M. J., 2001. International trade and labor demand elasticities. Journal of International Economics 54 (1), 27-56.

Suarez Serrato, J. C., Wingender, P., 2014. Estimating local fiscal multipliers, Working Paper.

Tolbert, C. M., Sizer, M., 1996. US commuting zones and labor market areas: A 1990 update. Staff Paper 9614, Economic Research Service.

Topalova, P., 2007. Trade liberalization, poverty and inequality: Evidence from indian districts. In: Harrison, A. (Ed.), Globalization and Poverty. University of Chicago Press. 
Topel, R. H., 1986. Local labor markets. Journal of Political Economy 94 (3), S111-S143. 


\section{Tables}

Table 1: Local Revenue and Expenditure Shares by Category

\begin{tabular}{|c|c|c|c|c|}
\hline & \multicolumn{2}{|c|}{1990} & \multicolumn{2}{|c|}{2007} \\
\hline & Mean & Std. Dev. & Mean & Std. Dev. \\
\hline \multicolumn{5}{|l|}{ Panel A: Revenue Shares by Category } \\
\hline Rev. from Own Sources in Tot. Rev. & 61.14 & 10.89 & 60.47 & 11.49 \\
\hline Gen. Rev. in Rev. from Own Sources & 84.36 & 12.35 & 85.30 & 11.68 \\
\hline Tax Rev. in Gen. Rev. from Own Sources & 57.34 & 12.88 & 56.31 & 13.47 \\
\hline Prop. Tax in Tax Rev. & 80.13 & 15.47 & 75.27 & 16.30 \\
\hline Sales and License Tax in Tax Rev. & 16.83 & 14.00 & 23.27 & 16.04 \\
\hline Int.gov. Transfers in Tot. Rev. & 38.86 & 10.89 & 39.54 & 11.49 \\
\hline Fed. gov. in Int.gov. Transfers & 8.33 & 5.93 & 8.99 & 6.31 \\
\hline State gov. in Int.gov. Transfers & 84.59 & 8.90 & 84.46 & 7.80 \\
\hline Local gov. in Int.gov. Transfers & 7.07 & 6.44 & 6.55 & 5.27 \\
\hline \multicolumn{5}{|l|}{ Panel B: Expenditure Shares by Category } \\
\hline Education & 44.25 & 9.88 & 43.56 & 10.47 \\
\hline Transportation & 6.77 & 3.51 & 5.77 & 3.54 \\
\hline Public Safety & 6.10 & 2.29 & 7.43 & 2.95 \\
\hline Government Administration & 5.12 & 1.52 & 5.40 & 2.63 \\
\hline Public Welfare and Housing & 3.76 & 3.42 & 3.58 & 3.05 \\
\hline Parks and Natural Resources & 2.03 & 1.27 & 2.48 & 1.82 \\
\hline Utilities & 13.87 & 9.49 & 13.28 & 8.79 \\
\hline Other & 18.10 & 8.06 & 18.49 & 9.71 \\
\hline \multicolumn{5}{|c|}{$\begin{array}{l}\text { Notes: Means and standard deviations calculated over } 722 \text { commuting zones for each year. Public safety includes } \\
\text { expenditures on police and fire protection, correction and protective inspection, and regulation. Utilities include water } \\
\text { supply, electric power, gas, sewerage, and solid waste management. Transportation includes expenditures on highways, } \\
\text { parking facilities, and transit subsides. Government administration includes financial administration, judicial and legal, } \\
\text { general public buildings, and miscellaneous commercial activities. Public welfare and housing includes local welfare } \\
\text { programs and public housing. Other includes expenditures on government-run liquor stores, insurance, ports and } \\
\text { airports, and expenditures that are classified as "other or unallocable". }\end{array}$} \\
\hline
\end{tabular}


Table 2: Summary Statistics

\begin{tabular}{|c|c|c|c|c|c|c|c|c|}
\hline & (1) & (2) & (3) & (4) & (5) & (6) & (7) & (8) \\
\hline & $\begin{array}{l}\text { Income } \\
\text { Per } \\
\text { Capita }\end{array}$ & $\begin{array}{l}\text { Poverty } \\
\text { Rate }\end{array}$ & $\begin{array}{c}\text { Median } \\
\text { Home } \\
\text { Price }\end{array}$ & $\begin{array}{l}\text { Local } \\
\text { Rev. Per } \\
\text { Capita }\end{array}$ & $\begin{array}{c}\text { Local } \\
\text { Expend. } \\
\text { Per } \\
\text { Capita }\end{array}$ & $\begin{array}{c}\text { Educ } \\
\text { Expend. } \\
\text { Per } \\
\text { Student }\end{array}$ & $\begin{array}{c}\text { Student- } \\
\text { Teacher } \\
\text { Ratio }\end{array}$ & $\begin{array}{c}\text { Prop. } \\
\text { Crime } \\
\text { Rate }\end{array}$ \\
\hline 1990 & $\begin{array}{l}25.23 \\
(4.44)\end{array}$ & $\begin{array}{l}16.97 \\
(6.94)\end{array}$ & $\begin{array}{c}66.11 \\
(36.52)\end{array}$ & $\begin{array}{c}2.57 \\
(0.99)\end{array}$ & $\begin{array}{c}2.54 \\
(0.96)\end{array}$ & $\begin{array}{c}5.47 \\
(1.42)\end{array}$ & $\begin{array}{l}16.56 \\
(4.64)\end{array}$ & $\begin{array}{c}33.50 \\
(17.07)\end{array}$ \\
\hline 2000 & $\begin{array}{l}30.18 \\
(5.43)\end{array}$ & $\begin{array}{l}14.63 \\
(5.66)\end{array}$ & $\begin{array}{c}84.71 \\
(44.41)\end{array}$ & $\begin{array}{c}3.20 \\
(1.06)\end{array}$ & $\begin{array}{c}3.17 \\
(1.02)\end{array}$ & $\begin{array}{c}7.12 \\
(1.53)\end{array}$ & $\begin{array}{l}14.49 \\
(2.34)\end{array}$ & $\begin{array}{c}27.37 \\
(12.56)\end{array}$ \\
\hline 2007 & $\begin{array}{l}30.86 \\
(5.30)\end{array}$ & $\begin{array}{l}15.86 \\
(5.40)\end{array}$ & $\begin{array}{l}109.03 \\
(73.95)\end{array}$ & $\begin{array}{c}3.87 \\
(1.43)\end{array}$ & $\begin{array}{c}3.77 \\
(1.41)\end{array}$ & $\begin{array}{c}8.98 \\
(2.78)\end{array}$ & $\begin{array}{l}14.18 \\
(2.68)\end{array}$ & $\begin{array}{c}25.89 \\
(11.14)\end{array}$ \\
\hline
\end{tabular}

Notes: Means and standard deviations (in parentheses) for commuting zones. All dollar values are in thousands of US $\$$ adjusted for inflation. $\mathrm{N}=722$ per year, except for student-teacher ratios and property crime rates per 1000 pop. due to missing values in the data. 
Table 3: Commuting Zones with Largest and Smallest Trade Shocks, 2000-2007

\begin{tabular}{lccc}
\hline & $\begin{array}{c}\text { Top Quartile } \\
\text { of Trade } \\
\text { Shocks }\end{array}$ & $\begin{array}{c}\text { Bottom } \\
\text { Quartile of } \\
\text { Trade Shocks }\end{array}$ & Difference \\
\hline$\Delta$ Imports per worker (IPW) & 4.31 & 0.24 & $4.07^{* * *}$ \\
$\Delta$ ln avg. HH income & -1.57 & 7.87 & $-9.45^{* * *}$ \\
$\Delta$ Poverty rate & 2.36 & -0.44 & $2.80^{* * *}$ \\
$\Delta$ ln med. value own. occ. housing & 13.84 & 23.90 & $-10.07^{* * *}$ \\
$\Delta$ ln total local rev. pc & 16.43 & 20.95 & $-4.53^{* * *}$ \\
$\Delta$ ln total local exp. pc & 14.70 & 18.99 & $-4.30^{* * *}$ \\
$\Delta$ ln local educ. exp. per school age & 19.84 & 26.05 & $-6.21^{* * *}$ \\
$\Delta$ Students per teacher & -0.20 & -0.45 & 0.25 \\
$\Delta$ ln property crimes & 2.73 & -21.38 & $24.11^{* * *}$ \\
\hline $\begin{array}{l}\text { Notes: Means for respective groups. Change in imports per worker is in thousands of US\$. All } \Delta \ln \\
\text { variables are multiplied by 100 to approximate changes measured in percentage points. }\end{array}$
\end{tabular}


Table 4: Effect of Chinese Import Exposure on Employment, Income, and Poverty

\begin{tabular}{|c|c|c|c|c|c|}
\hline \multicolumn{6}{|c|}{ Panel A: Employment and Income } \\
\hline & $(1)$ & $(2)$ & $(3)$ & $(4)$ & $(5)$ \\
\hline & $\begin{array}{c}\Delta \text { Share } \\
\text { unemployed }\end{array}$ & $\begin{array}{l}\Delta \text { Share not } \\
\text { in laborforce }\end{array}$ & $\begin{array}{l}\Delta \ln \text { avg. } \mathrm{HH} \\
\text { income }\end{array}$ & $\begin{array}{l}\Delta \text { ln avg. HH } \\
\text { wage inc. }\end{array}$ & $\begin{array}{l}\Delta \ln \text { avg. } \mathrm{HH} \\
\text { transfer inc. }\end{array}$ \\
\hline$\Delta$ Chinese imports per worker & $\begin{array}{c}0.221^{* * *} \\
(0.059)\end{array}$ & $\begin{array}{c}0.553^{* * *} \\
(0.157)\end{array}$ & $\begin{array}{c}-1.476^{* * *} \\
(0.416)\end{array}$ & $\begin{array}{c}-2.142^{* * *} \\
(0.595)\end{array}$ & $\begin{array}{c}2.119^{* * *} \\
(0.754)\end{array}$ \\
\hline$R^{2}$ & 0.40 & 0.39 & 0.68 & 0.43 & 0.52 \\
\hline $\mathrm{N}$ & 1,444 & 1,444 & 1,444 & 1,444 & 1,444 \\
\hline N Clusters & 722 & 722 & 722 & 722 & 722 \\
\hline \multicolumn{6}{|c|}{ Panel B: Income Distribution and Poverty } \\
\hline & $\begin{array}{c}\Delta \text { Share } \mathrm{HH} \\
\text { inc }<30 \mathrm{~K}\end{array}$ & $\begin{array}{c}\Delta \text { Share } \mathrm{HH} \\
\text { inc } 30-60 \mathrm{~K}\end{array}$ & $\begin{array}{c}\Delta \text { Share } \mathrm{HH} \\
\text { inc }>60 \mathrm{~K}\end{array}$ & $\Delta$ Pov. rate & $\begin{array}{l}\Delta \text { Child pov. } \\
\text { rate }\end{array}$ \\
\hline$\Delta$ Chinese imports per worker & $\begin{array}{c}0.704^{* * *} \\
(0.198)\end{array}$ & $\begin{array}{l}-0.172 \\
(0.151)\end{array}$ & $\begin{array}{c}-0.532^{* *} \\
(0.219)\end{array}$ & $\begin{array}{c}0.576^{* * *} \\
(0.154)\end{array}$ & $\begin{array}{c}0.867^{* * *} \\
(0.199)\end{array}$ \\
\hline$R^{2}$ & 0.60 & 0.69 & 0.26 & 0.35 & 0.44 \\
\hline $\mathrm{N}$ & 1,444 & 1,444 & 1,444 & 1,444 & 1,444 \\
\hline N Clusters & 722 & 722 & 722 & 722 & 722 \\
\hline \multicolumn{6}{|c|}{$\begin{array}{l}\text { Notes: All regressions include a constant, a dummy for the } 2000-2007 \text { period, geographic dummies for the nine Census divisions, } \\
\text { and the following start-of-period locality control variables: the share of employment in manufacturing, the college-educated share of } \\
\text { the population, the foreign-born share of the population, the share of women in the population, the share of routine occupations in } \\
\text { employment, and the average offshorability index of occupations. Observations are weighted by the start-of-period commuting zone } \\
\text { share of the national population. Robust standard errors, clustered at the commuting zone level, are reported in parentheses. } \\
{ }^{* * *} \text { denotes significance at the } 1 \% \text { level; }{ }^{* *} \text { denotes significance at the } 5 \% \text { level; }{ }^{*} \text { denotes significance at the } 10 \% \text { level. }\end{array}$} \\
\hline
\end{tabular}


Table 5: Effect of Chinese Import Exposure on Home Values

\begin{tabular}{|c|c|c|c|c|c|c|c|}
\hline & $\begin{array}{c}(1) \\
\Delta \ln \\
\text { median } \\
\text { val. own. } \\
\text { occ. } \\
\text { housing }\end{array}$ & $\begin{array}{c}(2) \\
\Delta \text { Median } \\
\text { val. own. } \\
\text { occ. } \\
\text { housing }\end{array}$ & $\begin{array}{c}(3) \\
\Delta \text { Share } \\
\text { homes }< \\
150 \mathrm{~K}\end{array}$ & $\begin{array}{c}(4) \\
\Delta \text { Share } \\
\text { homes } \\
150-300 \mathrm{~K}\end{array}$ & $\begin{array}{c}(5) \\
\Delta \text { Share } \\
\text { homes }> \\
300 \mathrm{~K}\end{array}$ & $\begin{array}{c}(6) \\
\Delta \ln \\
\text { median } \\
\text { rent }\end{array}$ & $\begin{array}{c}(7) \\
\Delta \text { Median } \\
\text { annual- } \\
\text { ized } \\
\text { rent }\end{array}$ \\
\hline$\Delta$ Chinese imports per worker & $\begin{array}{c}-5.404^{* * *} \\
(1.489)\end{array}$ & $\begin{array}{c}-7661.22^{* *} \\
(3379.50)\end{array}$ & $\begin{array}{c}1.536 \\
(1.264)\end{array}$ & $\begin{array}{l}2.469^{*} \\
(1.455)\end{array}$ & $\begin{array}{c}-4.005^{* *} \\
(1.773)\end{array}$ & $\begin{array}{c}-2.471^{* * *} \\
(0.648)\end{array}$ & $\begin{array}{c}-186.84^{* * *} \\
(62.20)\end{array}$ \\
\hline$R^{2}$ & 0.33 & 0.51 & 0.49 & 0.50 & 0.64 & 0.07 & 0.22 \\
\hline $\mathrm{N}$ & 1,444 & 1,444 & 1,444 & 1,444 & 1,444 & 1,444 & 1,444 \\
\hline N Clusters & 722 & 722 & 722 & 722 & 722 & 722 & 722 \\
\hline
\end{tabular}


Table 6: Effect of Chinese Import Exposure on Business Activity

\begin{tabular}{|c|c|c|c|c|}
\hline & $\begin{array}{c}(1) \\
\Delta \text { ln number } \\
\text { of establish- } \\
\text { ments }\end{array}$ & $\begin{array}{c}(2) \\
\Delta \ln \text { number } \\
\text { of est. }<50 \\
\text { empl. }\end{array}$ & $\begin{array}{c}(3) \\
\Delta \ln \text { number } \\
\text { of est. } \\
50-499 \text { empl. }\end{array}$ & $\begin{array}{c}(4) \\
\Delta \text { ln number } \\
\text { of est. } \geq \\
500 \text { empl. }\end{array}$ \\
\hline$\Delta$ Chinese imports per worker & $\begin{array}{l}-0.483 \\
(0.647)\end{array}$ & $\begin{array}{l}-0.395 \\
(0.629)\end{array}$ & $\begin{array}{l}-1.894^{*} \\
(1.029)\end{array}$ & $\begin{array}{c}-2.857^{* *} \\
(1.263)\end{array}$ \\
\hline $\begin{array}{l}R^{2} \\
\mathrm{~N} \\
\mathrm{~N} \text { Clusters }\end{array}$ & $\begin{array}{c}0.41 \\
1,444 \\
722\end{array}$ & $\begin{array}{c}0.41 \\
1,444 \\
722\end{array}$ & $\begin{array}{c}0.45 \\
1,444 \\
722\end{array}$ & $\begin{array}{c}0.31 \\
1,444 \\
722\end{array}$ \\
\hline \multicolumn{5}{|c|}{$\begin{array}{l}\text { Notes: All regressions include a constant, a dummy for the } 2000-2007 \text { period, geographic dummies for th } \\
\text { nine Census divisions, and the following start-of-period locality control variables: the share of employment in } \\
\text { manufacturing, the college-educated share of the population, the foreign-born share of the population, the shar } \\
\text { of women in the population, the share of routine occupations in employment, and the average offshorability } \\
\text { index of occupations. Observations are weighted by the start-of-period commuting zone share of the nationa } \\
\text { population. Robust standard errors, clustered at the commuting zone level, are reported in parentheses. } \\
{ }^{* * *} \text { denotes significance at the } 1 \% \text { level; }{ }^{* *} \text { denotes significance at the } 5 \% \text { level; }{ }^{*} \text { denotes significance at the } \\
10 \% \text { level. }\end{array}$} \\
\hline
\end{tabular}




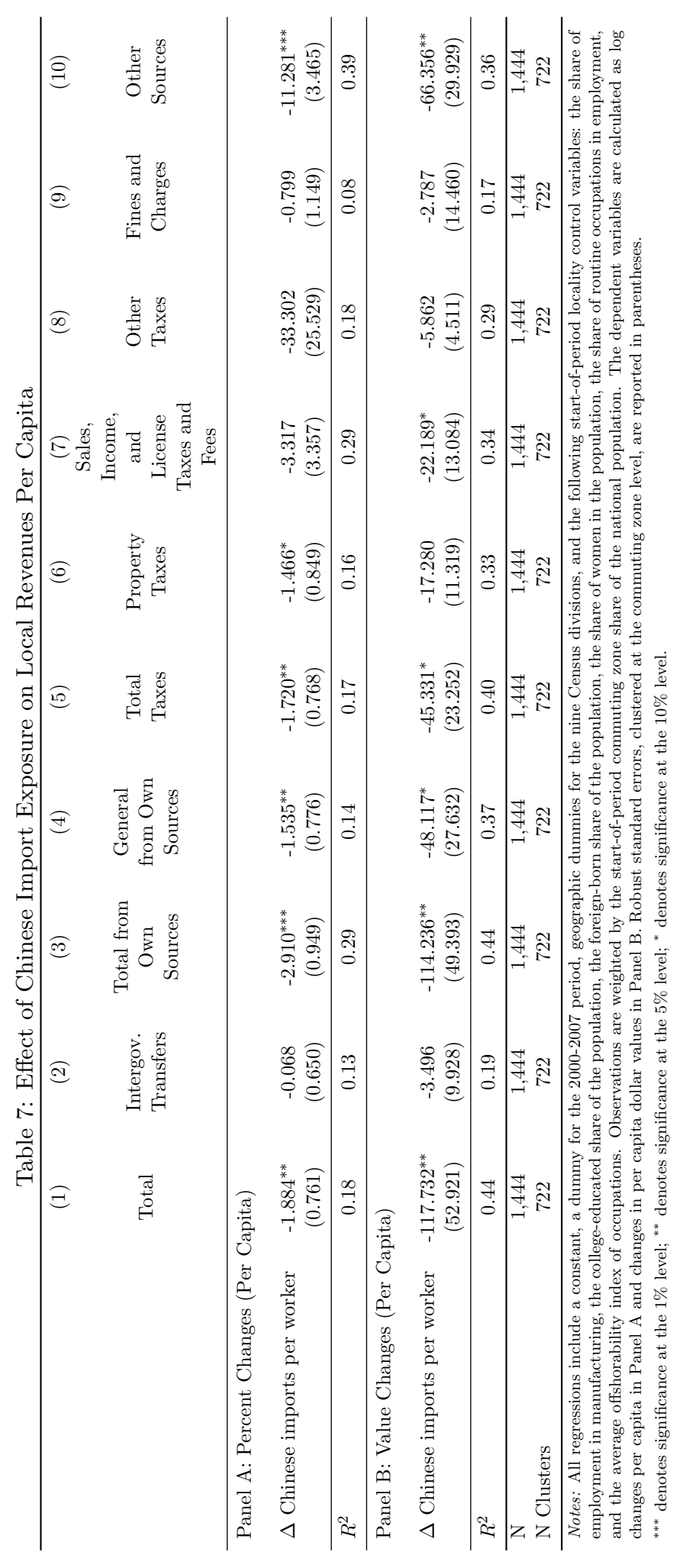




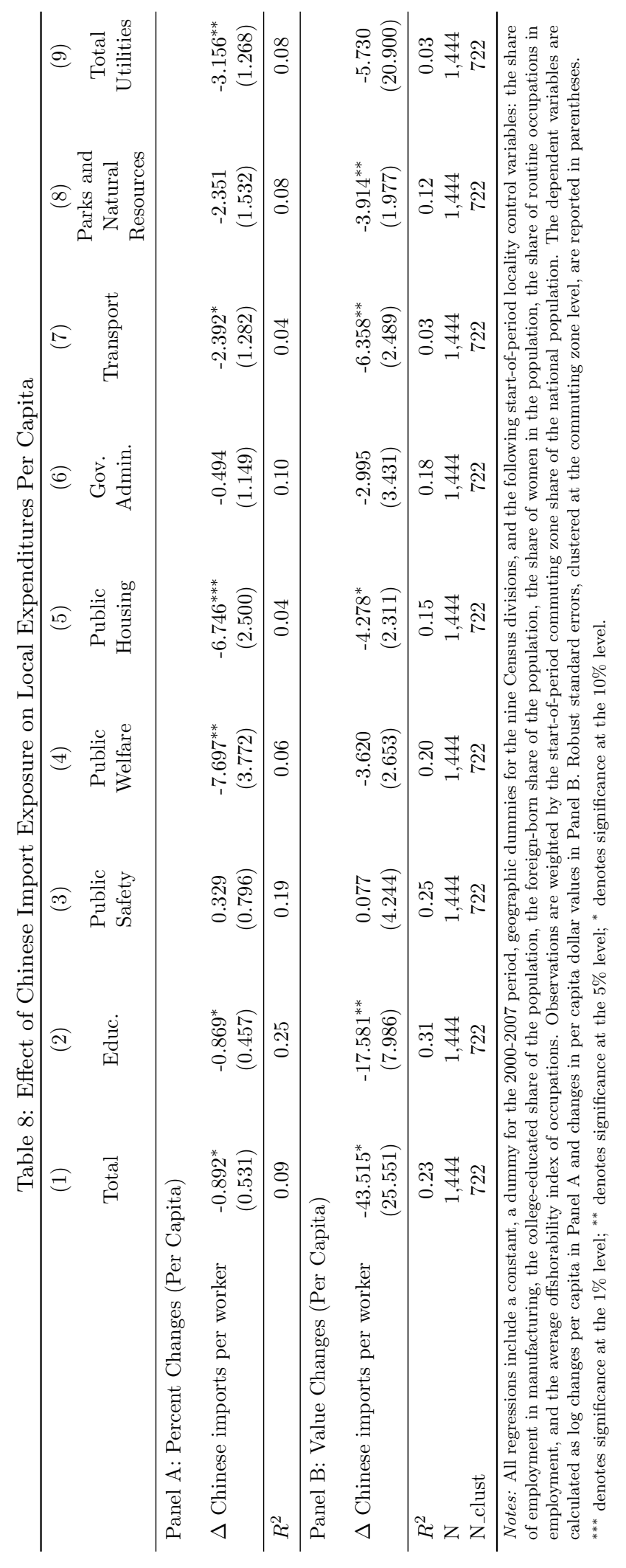


Table 9: Effect of Chinese Import Exposure on Provision of Local Public Goods

\begin{tabular}{|c|c|c|c|c|}
\hline & $\begin{array}{c}(1) \\
\Delta \ln \\
\text { property } \\
\text { crime }\end{array}$ & $\begin{array}{c}\Delta \text { ln violent } \\
\text { crime }\end{array}$ & $\begin{array}{c}(3) \\
\Delta \text { Student- } \\
\text { teacher } \\
\text { ratio }\end{array}$ & $\begin{array}{c}(4) \\
\Delta \text { PK12 } \\
\text { Student- } \\
\text { teacher } \\
\text { ratio }\end{array}$ \\
\hline$\Delta$ Chinese imports per worker & $\begin{array}{l}3.464^{* *} \\
(1.699)\end{array}$ & $\begin{array}{c}-0.117 \\
(1.451)\end{array}$ & $\begin{array}{l}0.209^{* *} \\
(0.098)\end{array}$ & $\begin{array}{l}0.253^{* *} \\
(0.099)\end{array}$ \\
\hline $\begin{array}{l}R^{2} \\
\mathrm{~N} \\
\mathrm{~N} \text { Clusters }\end{array}$ & $\begin{array}{c}0.38 \\
1,068 \\
568\end{array}$ & $\begin{array}{c}0.29 \\
1,049 \\
560\end{array}$ & $\begin{array}{c}0.12 \\
1,429 \\
722\end{array}$ & $\begin{array}{c}0.14 \\
1,429 \\
722\end{array}$ \\
\hline \multicolumn{5}{|c|}{$\begin{array}{l}\text { Notes: All regressions include a constant, a dummy for the } 2000-2007 \text { period, geographic dummies for the } \\
\text { nine Census divisions, and the following start-of-period locality control variables: the share of employment } \\
\text { in manufacturing, the college-educated share of the population, the foreign-born share of the population, } \\
\text { the share of women in the population, the share of routine occupations in employment, and the average } \\
\text { offshorability index of occupations. Observations are weighted by the start-of-period commuting zone share } \\
\text { of the national population. Robust standard errors, clustered at the commuting zone level, are reported in } \\
\text { parentheses. } \\
{ }^{* * *} \text { denotes significance at the } 1 \% \text { level; }{ }^{* *} \text { denotes significance at the } 5 \% \text { level; }{ }^{*} \text { denotes significance at the } \\
10 \% \text { level. }\end{array}$} \\
\hline
\end{tabular}




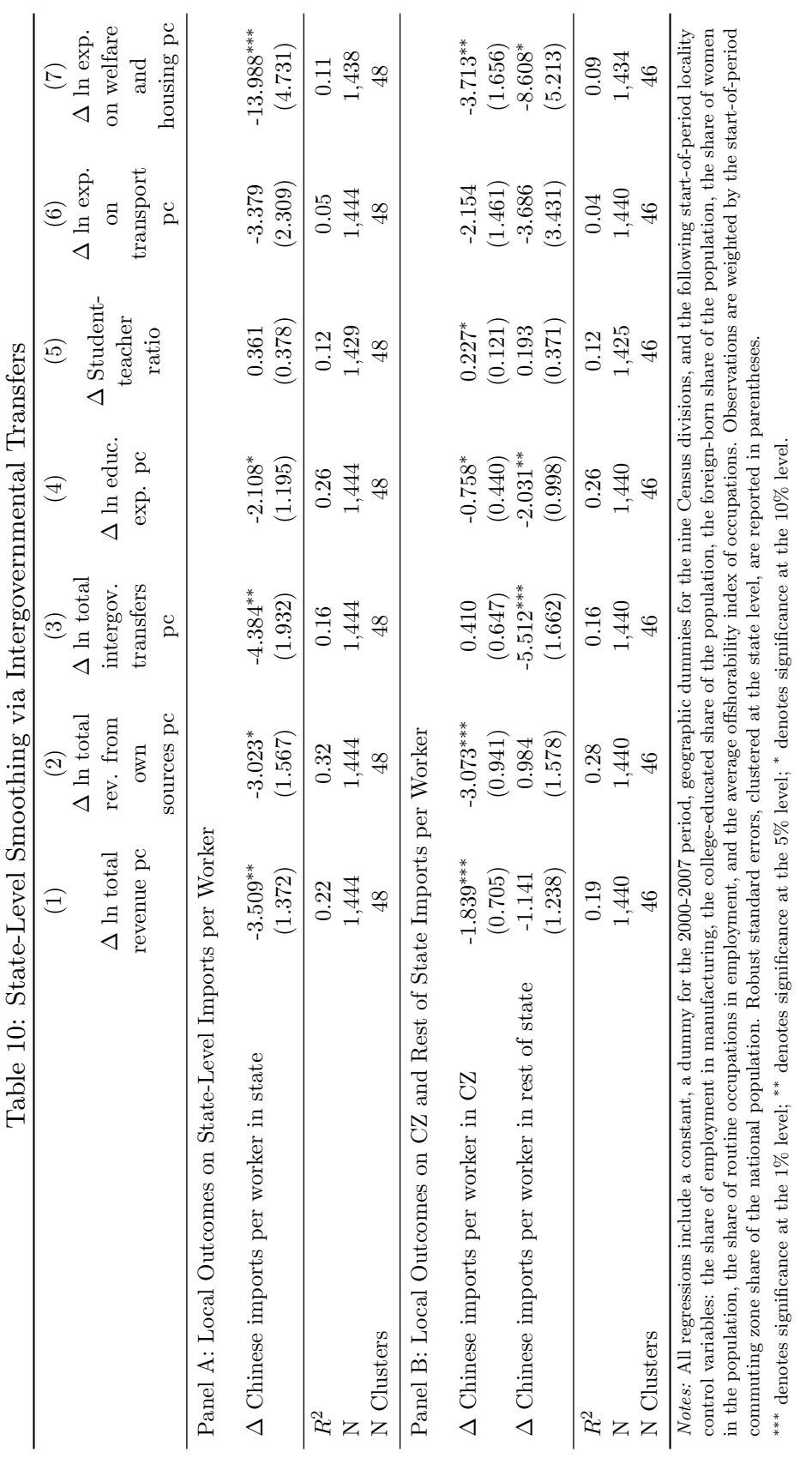


Table 11: Effect of Changes in Household Earnings on Local Outcomes

\begin{tabular}{|c|c|c|c|c|c|c|c|}
\hline \multicolumn{8}{|l|}{ Panel A: First Stage } \\
\hline \multicolumn{8}{|c|}{$\Delta \ln$ avg. HH income } \\
\hline \multicolumn{4}{|c|}{$\Delta$ Chinese imports per worker in Other Countries (Lagged) } & \multicolumn{4}{|c|}{$\begin{array}{c}-0.932^{* * *} \\
(0.274)\end{array}$} \\
\hline \multicolumn{4}{|l|}{$\begin{array}{l}\text { F-statistic } \\
R^{2}\end{array}$} & \multicolumn{4}{|c|}{$\begin{array}{c}11.57 \\
0.71\end{array}$} \\
\hline \multicolumn{8}{|l|}{ Panel B: Second Stage } \\
\hline & $\begin{array}{c}1) \\
\Delta \ln \\
\text { median val. } \\
\text { own. occ. } \\
\text { housing }\end{array}$ & $\begin{array}{c}(2) \\
\Delta \text { ln tot. } \\
\text { loc. rev. pc }\end{array}$ & $\begin{array}{c}(3) \\
\Delta \text { ln tot. } \\
\text { rev. from } \\
\text { own sources } \\
\text { pc }\end{array}$ & $\begin{array}{c}(4) \\
\Delta \ln \text { tot. } \\
\text { loc. exp. pc }\end{array}$ & $\begin{array}{c}(5) \\
\Delta \ln \text { tot. } \\
\text { educ. exp. } \\
\text { pc }\end{array}$ & $\begin{array}{c}(6) \\
\Delta \ln \\
\text { property } \\
\text { crimes per } \\
1000 \text { pop. }\end{array}$ & $\begin{array}{c}(7) \\
\Delta \text { Student- } \\
\text { teacher } \\
\text { ratio }\end{array}$ \\
\hline$\Delta \ln$ avg. HH income & $\begin{array}{c}3.661^{* * *} \\
(1.086)\end{array}$ & $\begin{array}{c}1.276^{* * *} \\
(0.378)\end{array}$ & $\begin{array}{c}1.971^{* * *} \\
(0.463)\end{array}$ & $\begin{array}{l}0.604^{*} \\
(0.361)\end{array}$ & $\begin{array}{l}0.589^{* *} \\
(0.288)\end{array}$ & $\begin{array}{l}-2.876^{*} \\
(1.518)\end{array}$ & $\begin{array}{c}-0.140^{* *} \\
(0.067)\end{array}$ \\
\hline$R^{2}$ & 0.36 & 0.10 & 0.13 & 0.13 & 0.01 & 0.02 & 0.03 \\
\hline $\mathrm{N}$ & 1,444 & 1,444 & 1,444 & 1,444 & 1,444 & 1,068 & 1,429 \\
\hline N Clusters & 722 & 722 & 722 & 722 & 722 & 568 & 722 \\
\hline \multicolumn{8}{|c|}{$\begin{array}{l}\text { Notes: The first stage, reported in Panel } \mathrm{A} \text {, is the same for all specifications, with } \Delta \text { Chinese imports per worker in other countries (lagged) as the } \\
\text { explanatory variable and } \Delta \ln \text { avg. HH income as the dependent variable. Second stage results are reported in Panel B, with } \Delta \ln \text { avg. HH income } \\
\text { as the explanatory variable and } \Delta \text { Chinese imports per worker in other countries (lagged) as the instrument. All regressions include a constant, a } \\
\text { dummy for the } 2000-2007 \text { period, geographic dummies for the nine Census divisions, and the following start-of-period locality control variables: the } \\
\text { share of employment in manufacturing, the college-educated share of the population, the foreign-born share of the population, the share of women in } \\
\text { the population, the share of routine occupations in employment, and the average offshorability index of occupations. Observations are weighted by } \\
\text { the start-of-period commuting zone share of the national population. Robust standard errors, clustered at the commuting zone level, are reported in } \\
\text { parentheses. }\end{array}$} \\
\hline
\end{tabular}


Table 12: Testing for Pre-Existing Trends in Main Dependent Variables

\begin{tabular}{|c|c|c|c|c|c|c|}
\hline \multirow[t]{2}{*}{ Dependent Variable } & \multirow[t]{2}{*}{ Explanatory Variable } & \multirow[b]{2}{*}{$\begin{array}{l}\text { Base } \\
\text { Case }\end{array}$} & \multirow{2}{*}{$\begin{array}{l}\text { (2) } \\
\text { Incl. } \\
\text { Dep. } \\
\text { Var. } 80-90 \\
\text { as Exog. } \\
\text { Control }\end{array}$} & \multirow{2}{*}{$\begin{array}{l}\text { (3) } \\
\text { Incl. } \\
\text { Dep. } \\
\text { Var. } 80-90 \\
\text { as Endog. } \\
\text { Control }\end{array}$} & \multirow{2}{*}{$\begin{array}{c}\text { (4) } \\
\text { Future } \\
\text { IPW pre- } \\
\text { dicting } \\
\text { current } \\
\text { Dep. } \\
\text { Var. }\end{array}$} & \multirow{2}{*}{$\begin{array}{c}(5) \\
\text { Future } \\
\text { IPW pre-- } \\
\text { dicting } \\
\text { current } \\
\text { Dep. } \\
\text { Var; } \\
\text { Region } \\
\text { FE }\end{array}$} \\
\hline & & & & & & \\
\hline \multirow{3}{*}{$\Delta \ln$ avg. $\mathrm{HH}$ income } & $\Delta$ Current Chinese imports per worker & $\begin{array}{c}-1.476^{* * *} \\
(0.416)\end{array}$ & $\begin{array}{c}-1.500^{* * *} \\
(0.419)\end{array}$ & $\begin{array}{c}-1.635^{* * *} \\
(0.439)\end{array}$ & & \\
\hline & $\Delta \ln$ avg. $\mathrm{HH}$ income $80-90$ & & $\begin{array}{c}3.746 \\
(4.545)\end{array}$ & $\begin{array}{c}24.804 \\
(18.116)\end{array}$ & & \\
\hline & $\Delta$ Future Chinese imports per worker & & & & $\begin{array}{c}0.008 \\
(0.008)\end{array}$ & $\begin{array}{c}-0.0001 \\
(0.0051)\end{array}$ \\
\hline \multirow{3}{*}{$\Delta \ln$ med. val. own. occ. housing } & $\Delta$ Current Chinese imports per worker & $\begin{array}{c}-5.404^{* * *} \\
(1.489)\end{array}$ & $\begin{array}{c}-5.188^{* * *} \\
(1.506)\end{array}$ & $\begin{array}{l}-4.047^{*} \\
(2.091)\end{array}$ & & \\
\hline & $\Delta \ln$ med. val. own. occ. housing $80-90$ & & $\begin{array}{c}-0.128^{* *} \\
(0.052)\end{array}$ & $\begin{array}{c}-0.804 \\
(0.632)\end{array}$ & & \\
\hline & $\Delta$ Future Chinese imports per worker & & & & $\begin{array}{c}2.747 \\
(2.457)\end{array}$ & $\begin{array}{c}0.026 \\
(1.595)\end{array}$ \\
\hline \multirow{3}{*}{$\Delta \ln$ tot. loc. rev. pc } & $\Delta$ Current Chinese imports per worker & $\begin{array}{c}-1.884^{* *} \\
(0.761)\end{array}$ & $\begin{array}{c}-1.832^{* *} \\
(0.754)\end{array}$ & $\begin{array}{c}-2.204^{* *} \\
(0.934)\end{array}$ & & \\
\hline & $\Delta \ln$ tot. loc. rev. $\mathrm{pc}_{80-90}$ & & $\begin{array}{c}-0.116^{* * *} \\
(0.035)\end{array}$ & $\begin{array}{c}0.715^{* * *} \\
(0.264)\end{array}$ & & \\
\hline & $\Delta$ Future Chinese imports per worker & & & & $\begin{array}{c}0.611 \\
(0.459)\end{array}$ & $\begin{array}{c}0.681 \\
(0.463)\end{array}$ \\
\hline \multirow{3}{*}{$\Delta \ln$ tot. loc. exp. pc } & $\Delta$ Current Chinese imports per worker & $\begin{array}{l}-0.892^{*} \\
(0.531)\end{array}$ & $\begin{array}{l}-0.893^{*} \\
(0.541)\end{array}$ & $\begin{array}{c}-1.239^{*} \\
(0.658)\end{array}$ & & \\
\hline & $\Delta \ln$ tot. loc. exp. $\mathrm{pc}_{80-90}$ & & $\begin{array}{c}0.002 \\
(0.060)\end{array}$ & $\begin{array}{c}0.577^{* * *} \\
(0.110)\end{array}$ & & \\
\hline & $\Delta$ Future Chinese imports per worker & & & & $\begin{array}{l}0.804^{*} \\
(0.474)\end{array}$ & $\begin{array}{l}0.906^{*} \\
(0.503)\end{array}$ \\
\hline \multirow{3}{*}{$\Delta \ln$ tot. educ. exp. pc } & $\Delta$ Current Chinese imports per worker & $\begin{array}{c}-.0 .869^{*} \\
(0.457)\end{array}$ & $\begin{array}{c}-0.970^{* *} \\
(0.441)\end{array}$ & $\begin{array}{l}-0.673 \\
(0.551)\end{array}$ & & \\
\hline & $\Delta \ln$ tot. educ. exp. $\mathrm{pc}_{80-90}$ & & $\begin{array}{c}-0.225^{* * *} \\
(0.039)\end{array}$ & $\begin{array}{c}0.433 \\
(0.200)\end{array}$ & & \\
\hline & $\Delta$ Future Chinese imports per worker & & & & $\begin{array}{c}0.268 \\
(0.774)\end{array}$ & $\begin{array}{c}0.404 \\
(0.597)\end{array}$ \\
\hline \multirow{3}{*}{$\Delta$ ln property crimes per 1000 pop. } & $\Delta$ Current Chinese imports per worker & $\begin{array}{l}3.464^{* *} \\
(1.699)\end{array}$ & $\begin{array}{l}3.659^{* *} \\
(1.588)\end{array}$ & $\begin{array}{c}4.628 \\
(5.175)\end{array}$ & & \\
\hline & $\Delta$ ln property crimes per 1000 pop. $80-90$ & & $\begin{array}{c}-0.368^{* * *} \\
(0.087)\end{array}$ & $\begin{array}{c}4.470 \\
(7.648)\end{array}$ & & \\
\hline & $\Delta$ Future Chinese imports per worker & & & & $\begin{array}{c}-0.404 \\
(1.550)\end{array}$ & $\begin{array}{c}0.829 \\
(1.335)\end{array}$ \\
\hline \multicolumn{7}{|c|}{$\begin{array}{l}\text { Notes: For reference, we show in column (1) the base case results from estimating equation } 3 \text { for several of our main dependent variables. In column (2), we include } \\
\text { the } 1980-1990 \text { values of the dependent variable in the specification. In column (3), we instrument for the 1980-1990 values of the dependent variable using } 1980 \\
\text { levels of the dependent variable. We regress our main dependent variables on future Chinese import exposure and omit all locality controls (column } 4 \text { ) except census } \\
\text { region fixed-effects (column 5). Observations are weighted by the start-of-period commuting zone share of the national population. The specifications for columns } \\
\text { (1)-(3) include a constant, a dummy for the 2000-2007 period, geographic dummies for the nine Census divisions, and the following start-of-period locality control } \\
\text { variables: the share of employment in manufacturing, the college-educated share of the population, the foreign-born share of the population, the share of women } \\
\text { in the population, the share of routine occupations in employment, and the average offshorability index of occupations. Robust standard errors, clustered at the } \\
\text { commuting zone level, are reported in parentheses. }\end{array}$} \\
\hline
\end{tabular}


Figure 1: Trade Shocks, Income, Home Values, Local Public Finances, and Public Good Provision
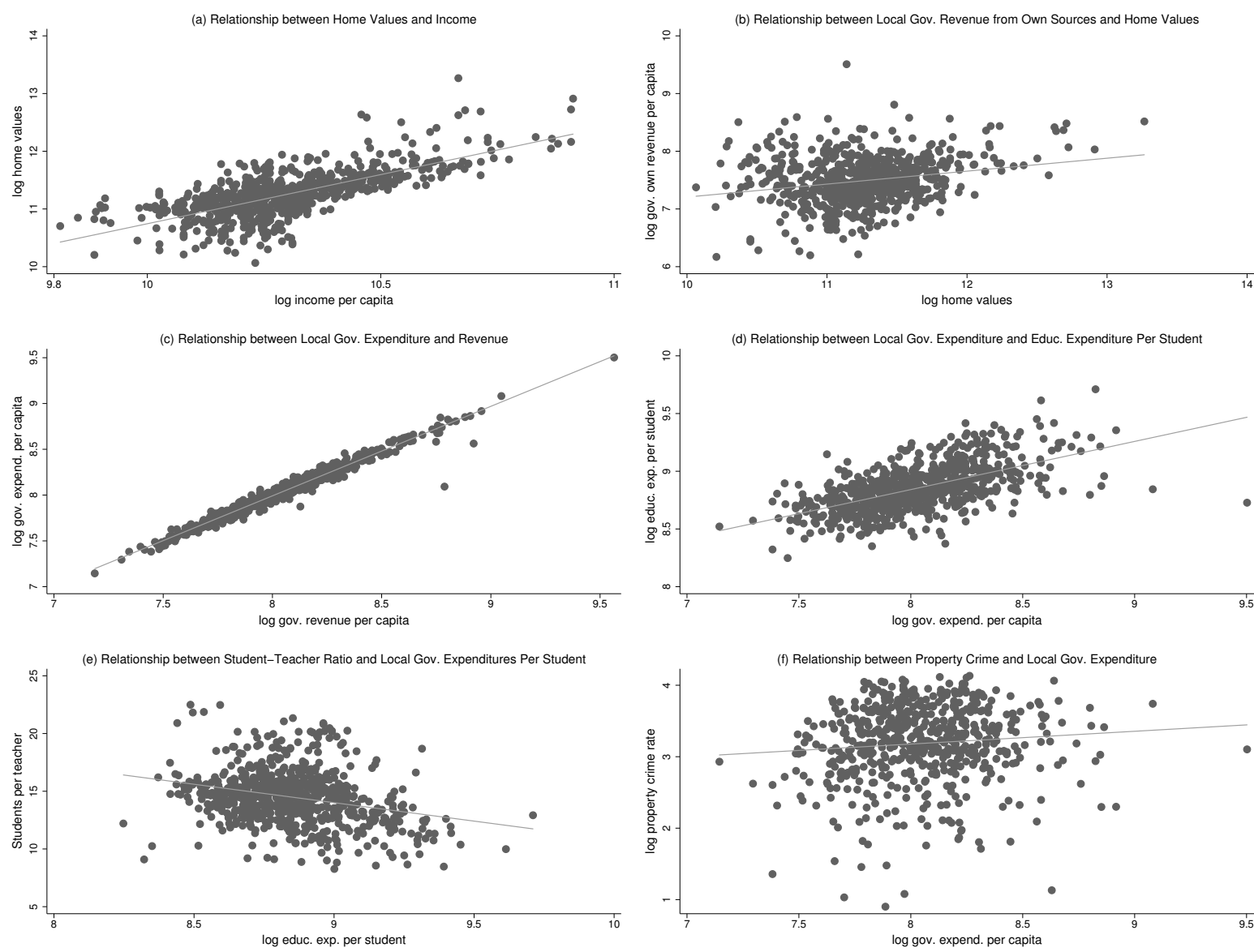

Notes: Correlations are based on raw data for $\mathrm{N}=722$ commuting zones (except for crime rates due to missing data) for 2000. The coefficient estimates (standard errors) on $\beta$ for $y=\alpha+\beta x+\varepsilon$, where $y$ is the $\mathrm{y}$-axis variable and $\mathrm{x}$ is the $\mathrm{x}$-axis variable are as follows: $1.703(0.069)$ for $(\mathrm{a})$; $0.138(0.028)$ for (b); 0.977 (0.011) for (c); 0.417 (0.031) for (d); -3.193 (0.433) for (e); and $0.179(0.081)$ for $(\mathrm{f})$. 


\section{Data Appendix}

This appendix contains detailed descriptions of the variables and data sources underlying our analysis. All variables were analyzed within a commuting zone unless otherwise noted. When changes in variables are referenced in the paper, the relevant time periods are from 1990 to 2000 and from 2000 to 2007; any exceptions are discussed below.

\section{A1.1. Chinese Import Shocks}

Information on Chinese import shocks comes from Autor et al. (2013), who compiled the data on US imports from China (1991-2007) at the six-digit Harmonized System product level using the United Nations Commodity Trade Statistics Database and mapped to four-digit SIC industries.

To get imports in per worker terms, the continental United States was divided into 722 commuting zones, based on county-level commuting data compiled by Tolbert and Sizer (1996) using the 1990 US Census. For each commuting zone, the County Business Patterns database was used to determine the local employment structure in 1980, 1990, and 2000. The data came from the US Census Bureau's Business Register of US companies. In cases where individual employment numbers were not reported directly, they were imputed based on aggregate employment in the industry, the number of firms in each industry, and typical firm size.

The instrument, the change in other high-income country imports of Chinese goods, was also compiled by Autor et al. (2013) using the same UN Comtrade database and the same methodology. Other high-income countries include Australia, Denmark, Finland, Germany, Japan, New Zealand, Spain, and Switzerland.

\section{A1.2. Local Government Finances}

Information about local government revenue and expenditure came from the US Census $\mathrm{Bu}-$ reau's historical data on State and Local Government Finances, the March 2013 version containing information from 1967-2007, for every five years (years ending with 2 and 7). The data for 1990 and 2000 are interpolated using data for 1987 and 1992, and 1997 and 2002, respectively. All variables were aggregated at the county government level. Variables described as per capita reflect the line item divided by the local population. Population data came from the Census Integrated Public Use Micro Samples for 1970, 1980, 1990, and 2000, and the American Community Survey for 2006 
to 2008, and then mapped in to commuting zones (Autor et al. (2013)). Definitions were informed by the US Census Bureau's “Glossary of Selected Terms Used in US Census Bureau Publications on City Government Finances".

Total revenue: The sum of all sources of revenue for the local government.

Total revenue from own sources: Includes general revenue generated from local taxes, charges, or other miscellaneous revenues, and revenue generated by government enterprises or utilities, but not intergovernmental transfers.

General revenue from own sources: Revenue generated from local taxes, charges, or other miscellaneous revenues, including property tax, sales tax, and income tax, parking fees, port fees, and parks and recreation fees, but not revenue from government enterprises or utilities, liquor stores, or employee-retirement and other insurance trust revenue.

Total taxes: Total tax revenue, including property tax, sales tax, income tax, gasoline tax, and alcohol and tobacco taxes.

Property taxes: Revenue from property taxes.

Sales, income, and license taxes and fees: Tax revenue from sales and income taxes and vehicle taxes, but excluding property tax.

Revenue from fines and charges: Revenue from miscellaneous charges and fees, such as airport fees, port fees, housing and community development charges, and sewerage fees.

Other taxes: Tax revenue from sources other than property tax, sales tax, income tax, and vehicle tax.

Intergovernmental transfers: Revenue transfers from state, federal, and other local governments received as fiscal aid in the form of shared revenues and grants-in-aid, as reimbursements for performance of general government functions and specific services for the paying of government (e.g., care of prisoners or contractual research), or in lieu of taxes. Excludes amounts received from other governments for sale of property, commodities, and utility services.

Total expenditure: The sum of all expenditures by the local government. 
Education expenditure: Expenditure on schools and other educational facilities and services, including public elementary and secondary and higher education, as well as payments to private institutions and special educational programs. Also includes school lunch services, athletic events, and other commercial or auxiliary services. Higher education includes universities, colleges, and junior or community colleges. Public libraries are included as well.

Public safety expenditure: Expenditure on police protection, fire protection, correctional facilities, and the regulation of private enterprises for the protection of the public.

Utility, sewerage, and solid waste management expenditure: Expenditure for construction of utility (water supply, electric light and power, gas supply, or transit system) facilities or equipment, for production and distribution of utility commodities and services (except those furnished to the parent city), and for interest on utility debt. Does not include expenditure in connection with administration of utility debt and investments (treated as general expenditure) and the cost of providing services to the parent city government (such costs, when identifiable, are treated as expenditure for the function served). Includes expenditure for sewerage and solid waste management.

Transportation expenditure: Expenditure on highways, parking facilities, water transport and terminals, and transit subsidies.

Government administration expenditure: Expenditures for judicial and legal services, public buildings, central staff services, financial administration, miscellaneous commercial activities.

Public welfare expenditure: Assistance to needy persons, including cash assistance, payments to private purveyors for medical care, burials, and other commodities and services, and provision and operation of welfare institutions. Also includes payments to other governments for welfare purposes, amounts for administration, support of private welfare agencies and other public welfare services.

Housing and community development expenditure: Housing and community development refers to city housing and redevelopment projects and regulation, promotion, and support of private housing and redevelopment activities.

Parks and natural resources expenditure: Expenditures on public parks and natural resources. 
Other expenditure: Remaining expenditures not included in the seven main categories described above.

\section{A1.3. Local Business Activity}

For each commuting zone, the County Business Patterns database was used to determine the number of firms. The data came from the US Census Bureau's Business Register of US companies and was then aggregated up to the commuting zone level. The database includes all companies with paid employees, covering most NAICS industries except for crop and animal production; rail transportation; the National Postal Service; pension, health, welfare, and vacation funds; trusts, estates, and agency accounts; private households; and public administration, as well as most establishments reporting government employees.

\section{A1.4. Local Outcomes}

Information about local outcomes, including crime rates, poverty rates, housing prices, household income, and income distribution, came from the US Census Bureau's USA Counties database.

Property Crime: the number of property crimes known to police, with values referenced for 1980, 1990, 2000, and 2007.

Violent Crime: the number of violent crimes known to police, with values referenced for 1981, 1990, 2000, and 2007.

Poverty Rate: The number of persons classified as poor divided by the number of persons for whom poverty status has been determined. Available for 1979, 1989, 1999, and 2005-09.

Child Poverty Rate: The number of related children under 18 years of age classified as poor divided by the number of related children under 18 years of age for whom poverty status has been determined. Available for 1979, 1989, 1999, and 2005-09.

Share of households with income below \$30,000: Aggregation of the number of households with income less than $\$ 10,000$, households with income of $\$ 10,000$ to $\$ 14,999$, households with income of $\$ 15,000$ to $\$ 19,999$, households with income of $\$ 20,000$ to $\$ 24,999$, and households with income of $\$ 25,000$ to $\$ 29,999$, divided by the total number of households. Available for 
1979, 1989, 1999, and 2005-09.

Share of households with income between $\$ 30,000$ and $\$ 60,000$ : Aggregation of the number of households with income of $\$ 30,000$ to $\$ 34,999$, households with income of $\$ 35,000$ to $\$ 39,999$, households with income of $\$ 40,000$ to $\$ 44,999$, households with income of $\$ 45,000$ to $\$ 49,999$, and households with income of $\$ 50,000$ to $\$ 59,999$, divided by the total number of households. Available for 1979, 1989, 1999, and 2005-09.

Share of households with income above \$60,000: Aggregation of the number of households with income of $\$ 60,000$ to $\$ 74,999$ and households with income of $\$ 75,000$ or more, divided by the total number of households. Available for 1979, 1989, 1999, and 2005-09.

Average household income: Includes total household income from all sources.

Average household wage income: Includes household income from employment and wage earnings only.

Average household transfer income: Includes household income from transfers such as social security, disability, and direct cash welfare assistance.

Share unemployed: The population with status "unemployed - civilian labor force" divided by the population with status "in labor force".

Share not in the labor force: The population age 16 years and over minus the population with employment status "in labor force", divided by the population age 16 years and over.

Median value of owner occupied housing: The median value of specified owner-occupied housing units. Values for 1980 (complete), 1990 (complete), and 2000 (sampled) drawn from the census. Values for 2005-2009 drawn from the American Community Survey.

\section{A1.5. Student-Teacher Ratios}

Information on student-teacher ratios was calculated using data from the National Center for Education Statistics within the US Department of Education and the Institute of Education Sciences for the 1992-1993, 2000-2001, and 2007-2008 academic years.

Totals for the number of teachers, the number of students, and students in pre-kindergarten through twelfth grade were accessed at the county level and then aggregated up to the commuting 
zone level.

Student-Teacher Ratio: The total number of teachers in the commuting zone divided by the total number of students enrolled.

Student-Teacher Ratio, Pre-K to 12th Grade: The total number of teachers in the commuting zone divided by the total number of students enrolled in pre-kindergarten through twelfth grade. 


\section{Additional Regressions and Robustness Checks}

Table A1: Effect of Chinese Import Exposure on Population Composition

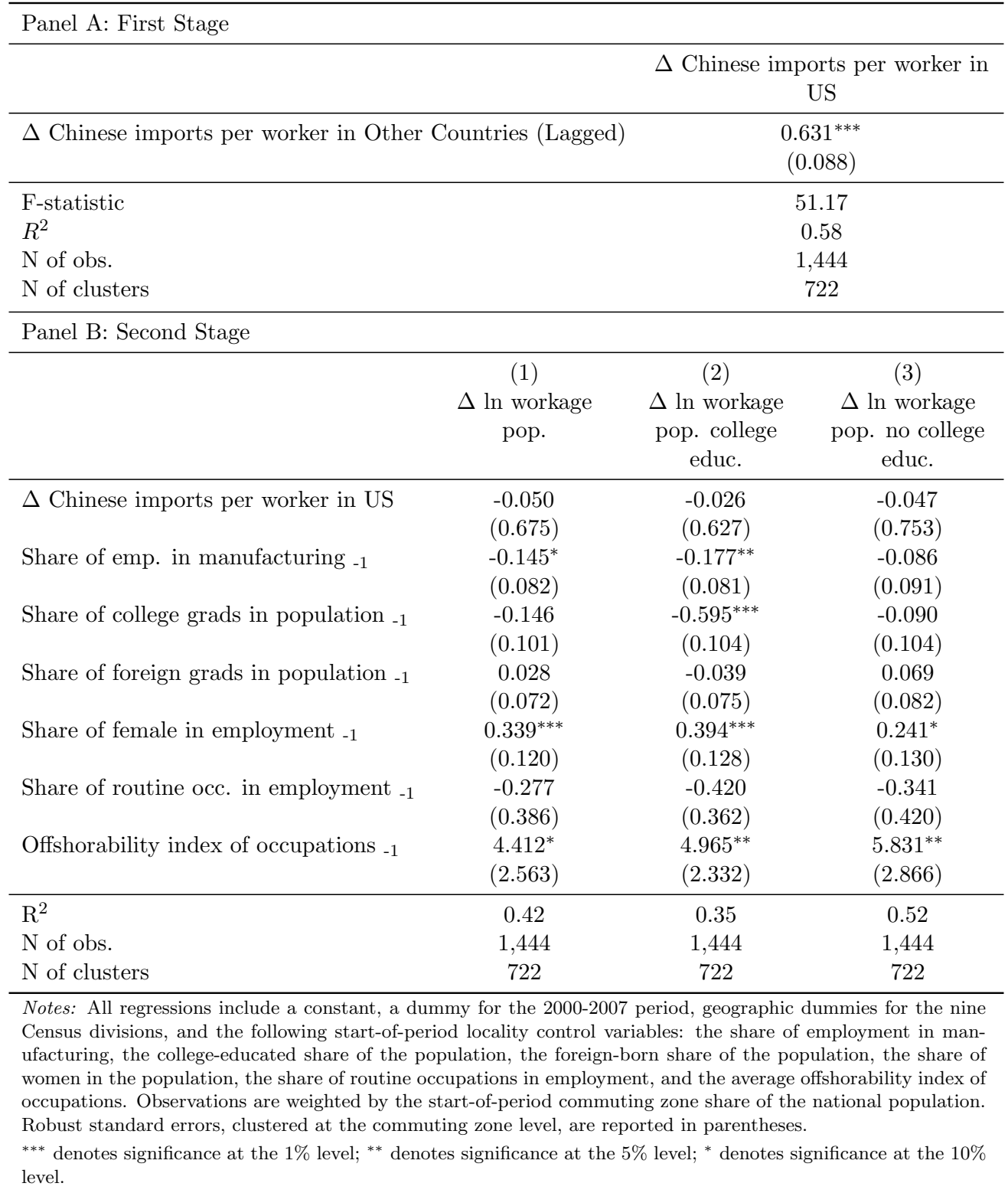


Table A2: Additional Robustness Checks

\begin{tabular}{lcccc}
\hline Dependent Variable & $(1)$ & $(2)$ & $(3)$ & $(4)$ \\
\hline$\Delta$ ln avg. HH income & $-1.637^{* * *}$ & $-1.637^{* * *}$ & $-1.401^{* * *}$ & $-1.580^{* * *}$ \\
& $(0.414)$ & $(0.322)$ & $(0.335)$ & $(0.502)$ \\
& & & & \\
$\Delta$ ln median val. own. occ. housing & $-5.240^{* * *}$ & $-5.240^{* *}$ & $-3.849^{* * *}$ & $-3.762^{* *}$ \\
& $(1.704)$ & $(2.199)$ & $(1.037)$ & $(1.854)$ \\
& & & & \\
$\Delta \ln$ total revenue pc & $-2.312^{* * *}$ & $-2.312^{* * *}$ & $-1.196^{* *}$ & $-2.448^{* * *}$ \\
& $(0.819)$ & $(0.755)$ & $(0.576)$ & $(0.939)$ \\
& & & & \\
$\Delta \ln$ total expenditure pc & $-1.381^{* * *}$ & $-1.381^{* *}$ & $-0.631^{*}$ & $-1.528^{* *}$ \\
& $(0.523)$ & $(0.644)$ & $(0.380)$ & $(0.601)$ \\
$\Delta$ ln property crimes per 1000 pop. & $4.153^{* *}$ & $4.153^{* *}$ & $4.805^{* * *}$ & $3.168^{*}$ \\
& $(2.032)$ & $(1.926)$ & $(1.477)$ & $(1.724)$ \\
$\Delta$ Student-teacher ratio & & & & \\
& $0.288^{* * *}$ & $0.288^{* *}$ & $0.105^{*}$ & $0.282^{* * *}$ \\
& $(0.108)$ & $(0.140)$ & $(0.061)$ & $(0.100)$ \\
\hline State fixed-effects & Yes & Yes & Yes & Yes \\
Commuting zone controls & Yes & Yes & No & Yes \\
Clustering & CZ & State & CZ & CZ \\
Sample & Full & Full & Full & Omit CA \\
\hline
\end{tabular}

Notes: Each cell represents the coefficient estimate on $\Delta$ Chinese imports per worker from a different specification. In column (1) state fixed effects (instead of region fixed effects) are included, in column (2) standard errors are clustered at the state-level (instead of commuting zone level), in column (3) all commuting zone level controls are omitted and in column (4) California is omitted from the sample. All regressions include a constant, a dummy for the 2000-2007 period, and state fixed-effects. The following are used as start-of-period locality control variables: the share of employment in manufacturing, the college-educated share of the population, the foreign-born share of the population, the share of women in the population, the share of routine occupations in employment, and the average offshorability index of occupations. Observations are weighted by the start-of-period commuting zone share of the national population. Robust standard errors, clustered at the commuting zone or state level, are reported in parentheses.

${ }^{* * *}$ denotes significance at the $1 \%$ level; ${ }^{* *}$ denotes significance at the $5 \%$ level; ${ }^{*}$ denotes significance at the $10 \%$ level. 